Zabytkoznawstwo i Konserwatorstwo XXXVIII, Toruń 2010

Dariusz Markowski, Sebastian Smagłowski

Uniwersytet Mikołaja Kopernika w Toruniu

\title{
Tajemnicze losy joannickich tablic herbowych ze Słońska oraz ich problematyka konserwatorska
}

\section{Joannici}

W

1096 roku rozpoczęła się z inicjatywy papieża Urbana II pierwsza wyprawa krzyżowa, zakończona zdobyciem Grobu Świętego i utworzeniem Królestwa Jerozolimy. Przez niemal 200 lat istnienia prowadziło ono nieustanną wojnę z islamem. Utrzymanie nowego państwa wymagało jednak stworzenia nowych formacji, pełniących jednocześnie funkcje porządkowe i militarne. Katolicki zakon joannitów powstał jeszcze przed pierwszą krucjatą, kiedy to mieszczanie z włoskiego państewka Amalfi założyli szpital św. Jana Chrzciciela ${ }^{1}$, przy którym szybko utworzono nieformalne bractwo zakonne, na czele którego stał charyzmatyczny brat Gérard. Za jego rządów bractwo przyjęło regułę św. Augustyna i przerodziło się w zakon szpitalny, ślubując czystość, ubóstwo i posłuszeństwo papieżowi, a także opiekę nad chorymi i potrzebującymi. Jego godłem stał się krzyż ośmioramienny, którego ramiona miały symbolizować osiem błogosławieństw. Po Gérardzie

1 Arcybiskup Królestwa Jerozolimy i ówczesny kronikarz krzyżowców Wilhelm z Tyru jako pierwszego patrona joannitów wspomina św. Jana Jałmużnika. Joannici uważaja jednak, że pierwszym ich patronem był św. Jan Chrzciciel, jako wyższy w hierarchii świętych. Twierdzą oni, że św. Jan Jałmużnik w VI w. odrestaurował wiele kościołów na Bliskim Wschodzie, w tym kościół św. Jana Chrzciciela, nazywany od tej pory przez wiernych także kościołem św. Jana Jałmużnika (znajdujący się na terenie zajmowanym później przez joannitów). 
władze w bractwie objął Rajmund de Puy, pod wodzą którego przekształciło się ono w zakon rycerski, uznany oficjalnie w 1113 roku przez papieża Paschalisa II. Początkowo zakon joannitów miał charakter międzynarodowy. Do jego obowiązków należało między innymi strzeżenie bezpieczeństwa wewnątrz państwa. W tym celu została utworzona cała sieć warowni i zamków w całej Palestynie, a wśród nich ogromna twierdza - szpital Margat - która stała się później oficjalną siedzibą zakonu. Bractwa religijne składały śluby zakonne, a ponadto ślub walki z niewiernymi. Natychmiast zyskały one aprobate i poparcie zarówno władców Jerozolimy, jak i papieży. Szczególnie papiestwo przyczyniło się do ich rozwoju, nadając im liczne przywileje. W owym czasie były to trzy zakony: Zakon Rycerzy Świątyni, zwanych templariuszami, Zakon Szpitala Najświętszej Marii Panny Domu Niemieckiego w Jerozolimie, czyli Krzyżacy, oraz Zakon Rycerzy Szpitala Jerozolimskiego św. Jana Chrzciciela, zwanych szpitalnikami lub joannitami. Również w Europie zakon zyskał wiele przywilejów - w krótkim czasie zaczęły funkcjonować liczne jego komandorie. Pomimo szeregu zmian nigdy nie zrezygnował on z działalności charytatywnej - utrzymywał na posiadanych terenach szpitale, a pomoc medyczna niesiona przez jego członków nie miała sobie równej w całej Europie. Największe szpitale joannici utrzymywali na szlakach pielgrzymów, w Messynie na Sycylii, Tarencie, Pizie, Astii, Barii, St.-Gilles, Marsylii, Sewilli. Jednakże wzrost dóbr na całym kontynencie i wielonarodowość członków stały się powodem podziału na osiem prowincji, tzw. Langue, czyli „języki”: Prowansja, Owenia, Francja, Włochy, Niemcy, Aragonia i Kastylia. Te dzieliły się na przeoraty, przeoraty na baliwaty, a te na komandorie, bedace najmniejszymi jednostkami administracyjnymi².

Po upadku Jerozolimy joannici przenieśli swój główny szpital do Akki, a siedzibę do Margat. Po zdobyciu w 1291 roku Akki przez Saracenów zakon przeniósł się razem z templariuszami na Cypr. Po likwidacji zakonu templariuszy papież przekazał większość ich dóbr i ziem joannitom, jednakże nie wszystkie posiadłości udało się im przejać. Nagły wzrost potegi umożliwiło zorganizowanie, pod wodzą bezwzględnego Fulko de Villareta, najazdu na wyspę Rodos będącą formalnie pod władzą Bizancjum. W 1310 r. szpitalnicy

2 T. W. Lange, Szpitalnicy. Joannici. Kawalerowie maltańscy, Warszawa 1999. 
przenieśli się na wyspe, gdzie po oficjalnym zaakceptowaniu przez papieża powstało państwo zakonne rządzone przez wielkiego mistrza ${ }^{3}$. Rycerze przesiedli się z koni na okręty, a ich państwo stało się szybko potęgą morską, kontrolującą handel we wschodniej cześci Morza Śródziemnego i wspomagającą wzrost zamożności włoskich miast-państw, w tym zwłaszcza Wenecji. Kontrola handlu morskiego bardzo przeszkadzała interesom imperium otomańskiego, dlatego podejmowało ono ciągłe ataki na Rodos zakończone wreszcie w 1521 roku sukcesem, który położył kres państwu zakonnemu na tej wyspie. Przez kilkanaście lat zakon tułał się po różnych krajach Europy, aż wreszcie cesarz niemiecki Karol V pozwolił w 1530 roku osiedlić się joannitom na Malcie, gdzie zbudowali port, szpital i warownie, z której ponownie zaczęli nękać okręty otomańskie. Spowodowało to szybką odpowiedź imperium w postaci inwazji, jednak długotrwałe oblężenie Malty w roku 1565 przez wojska Sulejmana Wspaniałego nie przyniosło efektu i zakon tym razem wygrał. W roku 1566 rozpoczęto budowę nowego miasta mającego stać się nową stolicą. Na cześć Jeana de la Valette, wielkiego mistrza w latach 1557-1568, dowodzącego wojskami zakonu podczas oblężenia, miasto to nazwano Vallettą (jest ono stolicą współczesnej Malty). Przez kolejne 200 lat zakon stawał się coraz bardziej świecki, aż do roku 1798, kiedy to Napoleon podbił wyspe w drodze do Egiptu. Zajęta bez większego oporu Malta została przekształcona w zamorską prowincję francuską. Większość dóbr, które joannici zostali zmuszeni pozostawić na Malcie została zajęta przez wojska francuskie. Nie cofnięto się nawet przed splądrowaniem kościołów, co wywołało bunt miejscowej ludności, początkowo przychylnej Francuzom.

Na skutek wojen napoleońskich w Europie zakon utracił też większość swoich komandorii, oprócz kilku w Czechach, i niemal całkowicie podupadł.

Wywołane przez Maltańczyków powstanie, wsparte przez floty angielską i portugalska, doprowadziło do zajęcia Malty w 1800 roku przez wojska brytyjskie. Dwa lata później Francja i Wielka Brytania zawarły traktat w Amiens, w którym jeden z punktów mówił o przywróceniu Malty zakonowi. Jednak rok później układ został zerwany i nie doszło do oddania wyspy joannitom.

3 M. M. Marrocco Trischitta, The Knights of Malta. A legend towards the future, Rzym 1999. 
Zakon ostatecznie musiał pogodzić się z jej utratą, kiedy w 1814 roku traktat paryski oficjalnie uznał brytyjskie zwierzchnictwo nad nią.

Po upadku Malty wielki mistrz Ferdynand von Hompesch z konwentem udał się do austriackiego Triestu. W roku 1799 po rezygnacji von Hompescha nowym wielkim mistrzem i protektorem joannitów został car Rosji Paweł I (wybrany 7 listopada)4. Od roku 1797 na terenie zaboru i Rosji działał przeorganizowany z przeoratu polskiego - katolicki przeorat Polski. W 1799 roku został utworzony także nowy prawosławny wielki przeorat Rosji. W tym czasie stolicą zakonu stał się Sankt Petersburg. W 1801 roku car Paweł I został uduszony przez członków swojej świty, wśród których było czterech kawalerów maltańskich. Następny car, Aleksander I, syn Pawła I, sam zrzekł się dziedziczenia stanowiska wielkiego mistrza, a na namiestnika joannitów mianował baliwa Mikołaja Sałtykowa. Nastęnie rada zakonu, za zgoda protektora cara Aleksandra I, zwróciła się w 1802 roku do papieża Piusa VII o wyznaczenie nowego wielkiego mistrza. W roku 1803 papież zatwierdził wybór, wspieranego przez prawosławny wielki przeorat Rosji, Jana Chrzciciela Tomassiego.

Po upadku Napoleona zakon odzyskał część swoich dóbr na Sycylii i w okolicach Ferrary, jednak trudności finansowe zmusiły joannitów do porzucenia ich i przeniesienia swojej siedziby do Rzymu. Zakon w dawnej formie próbował jeszcze odtworzyć cesarz Austrii Ferdynand I, mianowany wielkim mistrzem. Dzięki jego staraniom joannici odzyskali około 100 starych komandorii w Apulii i Lombardii, które zostały im ponownie zabrane przez Mussoliniego.

W XIX wieku rozproszeni po Europie kawalerowie maltańscy zaczęli zakładać nieformalne stowarzyszenia świeckie, będące odtworzeniem dawnej struktury przeoratów. Część z nich miała charakter katolicki, a część protestancki.

Pierwszym tego rodzaju zgromadzeniem było Maltańskie Stowarzyszenie Reńsko-Westfalskie, założone w 1806 roku, które grupowało katolickich

4 Do dzisiaj trwa dyskusja, czy prawosławny car mógł być de iure zwierzchnikiem ultrakatolickiego zakonu. 
członków dawnego zakonu. Jego konkurencją była, popierana przez królów Prus, protestancka komturia Brandenburgii zakonu joannitów, istniejąca od 1538 roku, rozwiązana na skutek sekularyzacji zakonów w Prusach w 1811 roku, odnowiona w 1856 roku, kiedy to stała się elitarnym stowarzyszeniem pruskiej szlachty. To ten zakon określa się na ogół mianem joannitów. Protestanccy joannici mają swe organizacje także w Szwecji (Johanniterorden), Holandii i Wielkiej Brytanii (Venerable Order of St. John). Organizacje te są uznawane przez zakon katolicki.

Oprócz tego powstawały też na ich wzór podobne stowarzyszenia w innych krajach - Anglii, Hiszpanii, Włoszech, Francji, Portugalii i Polsce. W okresie I i II wojny światowej organizowały one szpitale polowe, a w czasach pokoju prowadziły działalność charytatywną. Zakon stał się bardzo popularny w USA, gdzie przystapiło do niego ponad 2000 kawalerów. Charakter zakonny przywrócił kawalerom maltańskim papież Pius XII w 1953 roku. Jednocześnie zaczęło powstawać wiele organizacji podszywających się pod zakon. Konwent zakonny zmieniał kilkukrotnie siedzibe, by ostatecznie osiąść w Rzymie, w Palazzo di Malta, gdzie do dnia dzisiejszego znajduje sie jego główna siedziba ${ }^{5}$.

Jan Chrzciciel Ceschi a Santa Croce w 1872 roku stanął na czele Suwerennego Rycerskiego Zakonu Szpitalnego św. Jana z Jerozolimy z Rodos i z Malty i przeprowadził znaczące reformy w zakonie, na miare czasów. Zaakceptował liczne nowo powstające związki kawalerów maltańskich, popierał powstawanie narodowych związków (w 1920 roku powstał związek w Polsce). Jednocześnie rozszerzył działalność humanitarną - szpitale maltańskie były obecne na wszystkich frontach działań wojennych XX wieku.

Obecnie wszystkie katolickie stowarzyszenia kawalerów maltańskich mają jednakowy statut i są oficjalnie cześcią zakonu, a protestanckie stowarzyszenia angielskie i niemieckie funkcjonują niezależnie, ale stale współpracują i wymieniają doświadczenia z zakonem katolickim. Zakon w swojej części katolickiej liczy dzisiaj około 10000 członków zrzeszonych w sześciu malta.org.

5 Oficjalna strona internetowa Zakonu Kawalerów Maltańskich: http://www.orderof- 
wielkich przeoratach, czterech subprzeoratach i czterdziestu pięciu związkach narodowych, 150 członków to Polacy. W 1994 roku zakon uzyskał status oficjalnego, stałego obserwatora przy ONZ. Stanowi suwerenne państwo i jest oficjalnie uznawany przez rządy 92 krajów na świecie, przy których ma on swoich ambasadorów. Na jego czele stoi Szkot z pochodzenia, wielki mistrz Andrew Bertie.

\section{Baliwat brandenburski}

Joannici zostali sprowadzeni na ziemie polskie przez Henryka księcia sandomierskiego, który przed rokiem 1166 nadał im miasto Zagość z kilkoma wsiami. W 1187 roku otrzymali oni kościól św. Michała Archanioła w Poznaniu, przemianowany na kościół św. Jana Jerozolimskiego (Jana Chrzciciela), a wkrótce potem kościoły w Tyńcu nad Ślęzą, w Bardzie i Strzegomiu na Śląsku, gdzie powstały tzw. komandorie joannitów.

$\mathrm{Na}$ Pomorze Gdańskie joannitów sprowadził prawdopodobnie (w roku 1198 lub wcześniej) książę świecki Grzymisław, któremu zawdzięczały swoje powstanie domy zakonne w Starogardzie i Skarszewach. W 1278 roku dzięki nadaniu Mściwoja II powstała kolejna placówka w Lubiszewie, gdzie już w roku 1198 rycerze św. Jana uzyskali patronat nad kościołem św. Trójcy. Po zajęciu Pomorza Gdańskiego przez Krzyżaków joannici rozwijali jeszcze przez jakiś czas swoje posiadłości, m.in. w 1320 roku doprowadzili do nadania Skarszewom praw miejskich, ale ostatecznie w 1370 roku odsprzedali wszystkie swoje dobra w tej dzielnicy zakonowi krzyżackiemu.

W XII wieku i później powstały dalsze komandorie, m.in. na Pomorzu Zachodnim (Stargard 1186) i w Nowej Marchii (ziemia lubuska), m.in. w Słońsku i w Łagowie, a po kasacie zakonu templariuszy - w Chwarszczanach. W 1775 roku powstał w Polsce wielki przeorat, połączony w 1797 roku przez cara Pawła I z nowym przeoratem rosyjskim w jedno zgromadzenie (rozwiązane formalnie w 1817 r., choć potwierdzone przyjęcia nowych kawalerów, w większości Polaków, trwały do 1824 r.). Ostatnią komandorią była komandoria poznańska, skasowana przez władze pruskie w 1832 roku.

$\mathrm{Na}$ ziemie polskie, tereny dawnej Marchii Brandenburskiej, leżące na styku trzech państewek bęących ze sobą w częstych konfliktach, Henryk Brodaty i Władysław Odonic sprowadzili templariuszy. Nadanie tych ziem 
zakonnikom było jedynym sposobem na zabezpieczenie ich przed rubieża$\mathrm{mi}^{6}$. Po kasacie zakonu templariuszy w 1312 roku, na mocy bulli papieża Klemensa V, wszelkie jego dobra, m.in. na terenach Marchii wraz z komandoriami w Leśnicy, Chwarszczanach, Sulęcinie, Wielkiej Wsi, Czaplinku i Rurce, przeszły w ręce joannitów ${ }^{7}$. Wraz z istniejącymi ośrodkami w Stargardzie, Suchaniu, Pęzinie i Sławnie oraz w Meklemburgii (Werben, Nemerow, Gardow, Mirow, Eixen i Brunszwik) tworzyły bardzo silne skupisko na niewielkim stosunkowo obszarze. Trzej komandorzy brandenburscy wybrali własnego mistrza zwanego Herrenmeister. Przeor Niemiec zaakceptował tę sytuacje, a w XV wieku autonomię potwierdził papież Paweł II. Powstała nowa jednostka, tzw. baliwat brandenburski, który był jedynie zobowiązany do płacenia responsium i do uczestnictwa wielkiego mistrza lub pełnomocnika w konwentach wielkiego przeoratu. Niezależność od przeoratu baliwat osiągnął, ustalając swoją stolicę zakonną. Został nią nabyty w 1426 roku Słońsk ${ }^{8}$, którego okolice wchodziły od roku 1249 w skład Marchii. Pierwszym udokumentowanym właścicielem miejscowości była rodzina Wedlów, która uzyskała od margrabiego Ludwika pozwolenie na budowę zamku, a od roku 1375 rodzina Vockenrode. W 1415 roku zamek został sprzedany Henrykowi Kinichowi, a po jego śmierci, jako spadek, został włączony do dóbr elektora brandenburskiego. Umową z dnia 20 marca 1426 roku, podpisaną przez elektora w Berlinie, „Schloss und Stadt Sonnenburg” z resztą spadku przekazano joannitom ${ }^{9}$. Dnia 18 maja 1427 roku baliw Baltazar von Schliben przejął dobra pod zarząd zakonu. Joannici zburzyli zamek, wznosząc na jego miejscu w latach 1427-1429 większy, przeznaczony na siedzibę baliwa. Średniowieczna forteca była przebudowywana dwukrotnie, w latach 1545-1564 przez baliwa Tomasza von Runie i w latach 1661-1668 przez baliwa Jana Maurycego księcia Nassau, według projektu Piotra Posta z Hagi, z wykorzystaniem

$6 \quad$ Za T. W. Lange: J. Pflugk-Harttungka, Die Anfänge des Johanniterordens in Deutschland besonderes in der Mark Brandenburg und in Mecklenburg, Berlin 1899.

7 Zob. A. Zieliński, Tajemnice polskich templariuszy, Warszawa 2003.

8 T. W. Lange, Szpitalnicy.

9 Strona internetowa ziemi lubuskiej. Informacje na temat historii regionu i architektury: http://www.ziemia-lubuska.pl. Podobne informacje można również odnaleźć na stronie wydawnictwa zajmującego się opracowaniem programu multimedialnego o historii fortyfikacji: http://www.zamki.pl i http://www.sonnenburg.zamki.pl. 
wcześniejszego, średniowiecznego założenia ${ }^{10}$. Związki z Rodos stawały się coraz bardziej luźne pomimo regularnie płaconego responsium i udziału członków baliwatu w obronie wyspy. W wieku XVI szerzyła się reformacja, baliwowie coraz częściej wstępowali w związki małżeńskie, zacieśniały się więzy z Hohenzollernami - od 1629 roku funkcja wielkiego mistrza wiąże się na stałe z tym domem. W wieku XVIII baliwat brandenburski stał się już zupełnie świeckim stowarzyszeniem szlacheckich rodów pruskich. Jego członkowie byli uroczyście pasowani na rycerzy joannitów w dzień św. Jana w kościele w Słońsku. W 1809 roku Prusy przegrały wojnę z Napoleonem, kontrybucja wojenna nałożona przez Francję miała być spłacana z dochodów ze skonfiskowanych dóbr zakonnych ${ }^{11}$. W praktyce baliwat przestał istnieć, a zamek w Słońsku pełnił nawet przez pewien czas funkcje więzienia ${ }^{12}$.

W 1852 roku Fryderyk Wilhelm IV odbudował baliwat pod nazwa Balley Brandenburg des Ritterlichen Ordens St. Johannis vom Spital zu Jerusalem $^{13}$, ustanawiając Słońsk stolicą i przywracając zamek ponownie do życia. Pruski nastepca tronu Fryderyk Karol Aleksander został mistrzem Johanniterorden, a zakon stał się ekskluzywną organizacją charytatywną, opiekująca się wieloma szpitalami i kultywującą tradycje baliwatu brandenburskiego. Dzięki staraniom nowo powstałego stowarzyszenia w latach 1862-1884 zamek został przebudowany, pełniąc od tej pory funkcje reprezentacyjne i muzealne.

Kościół w Słońsku znów stał się miejscem uroczystych spotkań, a w dzień św. Jana członkowie zakonu byli pasowani na rycerzy. Bogactwo i przepych stowarzyszenia podkreślał między innymi bogaty wystrój wnętrz zarówno kościoła, jak i zamku (zob. il. 1, 2). Ściany Sonnenburga - jak potocznie go nazywano - były zdobione portretami wielkich mistrzów ${ }^{14}$, a w głównej sali rycerskiej znajdowała się wspaniała galeria tablic herbowych. Zamek został

10 T. W. Lange, Dokumenty joannickie/maltańskie w Archiwum Państwowym w Poznaniu, „Poznański Rocznik Archiwalno-Historyczny”, 2001-2002, nr 8/9.

11 A. Radziwiłl, W. Roszkowski, Historia 1789-1871, Warszawa 1997.

12 B. Grabowska, Zamek joannitów w Stońsku, „Trakt. Warta-Odra”, 2004, nr 25.

13 T. W. Lange, Szpitalnicy.

14 Fot. 3, [w:] Joannici i ich mistrz Jan Maurycy von Nassau-Siegen, Wojewódzka Miejska Biblioteka Publiczna w Gorzowie Wielkopolskim, Gorzów Wielkopolski 2006. 
poważnie zniszczony ${ }^{15} \mathrm{w}$ czasie II wojny światowej, a jego wyposażenie wywieziono w nieznanym kierunku ${ }^{16}$. Opuszczony po wojnie, ulegał dalszej dewastacji i destrukcji. W 1975 roku spłonął w niewyjaśnionych okolicznościach. Nieoficjalnie mówi się o tym, że został on podpalony na polecenie ówczesnych władz, aby uniknąć ogromnych kosztów, jakie należałoby przeznaczyć na jego odrestaurowanie.

\section{Joannickie tablice herbowe ze Słońska}

Reprezentacyjne tablice herbowe, dekorujące wnętrza słońskiego zamku, wykonane na drewnianych deskach, były poświęcone kawalerom zakonu joannitów baliwatu brandenburskiego. Najstarsze spośród nich pochodzą z XVII i XVIII wieku, jednak większość, a było ich na zamku i w kościele około 1300, datuje się na połowę i koniec XIX wieku, okres ożywionej działalności Balley Sonnenburg. Zespół tablic był uzupełniany jeszcze w pierwszej połowie XX wieku, nawet do 1942 roku. Tablice herbowe, średnio o wysokości $70 \mathrm{~cm}$ i szerokości $50 \mathrm{~cm}$, zostały wykonane w technice olejnej na deskach dębowych, jodłowych bądź sosnowych i sporadycznie na płótnie ${ }^{17}$. Dzieliły się na dwie grupy. Większe, bardziej okazałe i umieszczane wyżej na ścianach, upamiętniały wielkich mistrzów ${ }^{18}$.

W 1945 roku tablice zostały pozyskane wraz ze słońskimi archiwaliami przez Archiwum Akt Dawnych w Warszawie, mieszczące się w pałacu Pod Blachą, a następnie przekazane na Zamek Królewski w Warszawie. W archiwum zakładowym Muzeum Lubuskiego im. Jana Dekerta w Gorzowie Wielkopolskim znajduje się sensacyjny dokument z 1964 roku, w którym jest mowa o zamiarze zorganizowania konwoju ciężarówek w celu przywiezienia tablic do zbiorów tego muzeum. Liczebność zespołu szacowano na

15 Pojawiają się rozbieżności w informacjach podawanych w publikacjach w Polsce i w Niemczech. Autorzy niemieccy podają, że zamek przetrwał wojnę w nienaruszonym stanie.

16 B. Grabowska, op. cit.

17 Joannici i ich mistrz.

18 Najprawdopodobniej było ich około 33. 
2000 sztuk, w związku z czym planowano przyjęcie dodatkowo jednego asystenta muzealnego. Niestety, z nieznanych przyczyn, do realizacji tego zamierzenia nigdy nie doszło.

Tablice ponownie pojawily się w latach 80. w Warszawie. W 1988 roku 1140 tablic sprzedano za granice za 35 tys. dolarów ${ }^{19}$. Inne źródło podaje, że 1000 tablic przekazano brytyjskiej firmie jako ekwiwalent wynagrodzenia za prace remontowe przy Zamku Królewskim w Warszawie ${ }^{20}$. Nowy właściciel szybko uzyskał pozwolenie na ich wywóz z kraju, skąd następnie trafiły do Szwecji i tam zostały wystawione przez kolekcjonera Roya Gustafssona w Muzeum Historycznym w Sztokholmie. W przeciaggu krótkiego czasu wartość zespołu wzrosła wielokrotnie, sięgając kwoty $5 \mathrm{mln}$ dolarów. Według specjalistów niektóre obiekty mogły wówczas mieć wartość nawet około 100000 marek.

Na tym jednak nie koniec. W podziemiach Zamku Królewskiego w Warszawie odnaleziono jeszcze około 140 tablic, w większości w formie destruktów. Ich właścicielem jest Skarb Państwa, reprezentowany przez Lubuskiego Wojewódzkiego Konserwatora Zabytków. Obecnie w gorzowskim urzędzie konserwatorskim znajdują się 123 tablice, wśród nich cztery konserwowane w ZKMiRzP UMK. W jaki sposób znalazły się one w Gorzowie - dokładnie nie wiadomo.

Znamienne, że po tablice herbowe chciano ponownie sięgnąć w końcu lat 90. XX wieku, kiedy zamierzano wykupić obraz Gabriela de Metzu Praczka, będący w posiadaniu domu aukcyjnego w Nowym Jorku. Obraz ten, przechowywany przed wojną w pałacu Łazienkowskim w Warszawie, został zrabowany przez Niemców i stanowił przez długie lata jedno z najbardziej poszukiwanych dzieł sztuki przez stronę polska. W każdym razie nadających się do sprzedaży tablic herbowych w zbiorach polskich już nie było i, rzecz jasna, nie można ich było sprzedać powtórnie ${ }^{21}$.

19 Joannici i ich mistrz.

20 W. Kowalski, Miedzynarodowo-prawne implikacje ochrony dziedzictwa kulturowego na zachodnich i pótnocnych ziemiach Polski, [w:] Ochrona dziedzictwa kulturowego zachodnich i pótnocnych ziem Polski, pod red. J. Kowalczyka, Warszawa 1995, s. 20.

21 Joannici i ich mistrz. 
W listopadzie 2004 roku cztery ze wspomnianych tablic, w większości w formie destruktów, zostały przekazane do Zakładu Konserwacji Malarstwa i Rzeźby Polichromowanej UMK przez Delegaturę Wojewódzkiego Urzędu Konserwatorskiego w Gorzowie Wielkopolskim w celu wykonania ich pełnej konserwacji i restauracji w ramach zajęć dydaktycznych. W kraju pozostały jedynie połamane i zniszczone herby, wśród których znalazły się konserwowane obiekty ${ }^{22}$. Zniszczenia pochodzą najprawdopodobniej z czasów końca II wojny, wcześniej wspomniane tablice nie były konserwowane. Prace konserwatorsko-restauratorskie przy dwóch tablicach - pierwszej poświęconej Augustowi Heinrichowi Graffowi von Wartensleben i drugiej poświęconej Georgowi Albrechtowi von Brandenburg - zostały zakończone, a obiekty przekazane właścicielowi. Przy dwóch tablicach - pierwszej z herbem Friedricha Ludwiga Wilhelma Philippa von Vincke i drugiej z herbem Wilhelma Christiana Gottloba von Pöllnitz - prace konserwatorskie są na ukończeniu.

\section{Tablica z herbem Augusta Heinricha Graffa von Wartensleben ${ }^{23}$}

Tablica ta powstała w końcu XIX wieku i jest poświęcona Augustowi Heinrichowi Graffowi von Wartensleben (zob. il. 3-5), członkowi zakonu joannitów pasowanemu na rycerza w 1772 roku, a wywodzącemu się ze znamienitego austriackiego rodu von Wartensleben, który był związany z joannitami już od czasu wypraw krzyżowych.

Tablica jest wykonana na podłożu drewnianym o wymiarach $68,5 \mathrm{~cm} \times$ $\times 39 \mathrm{~cm} \times 1,6 \mathrm{~cm}$. Dolne pole, stanowiące 1/3 powierzchni, zawiera złotą, ozdobną inskrypcję umieszczoną na czarnym tle. Pomimo że każdy z wersów

22 Z informacji uzyskanych od barona Friedricha Adolpha Freiherr von Dellingshausena, członka obecnego stowarzyszenia joannitów brandenburskich, jak również z pracy Wojciecha Kowalskiego cytowanej powyżej wynika, że zakon stara się odzyskać swoją prawowitą własność, jednakże skomplikowana sytuacja prawna wynikająca ze zmian geopolitycznych po II wojnie światowej uniemożliwia takie zabiegi.

23 Prace konserwatorskie wykonał A. Nóżka pod kier. S. Kamińskiego, Dokumentacja prac konserwatorskich i restauratorskich (nr inw. 1312), Zakład Konserwacji Malarstwa i Rzeźby Polichromowanej UMK w Toruniu, 2007. 
jest pozbawiony swojego początku, ze względu na ubytek lewego fragmentu podobrazia, możliwe jest odczytanie inskrypcji, której treść brzmi:

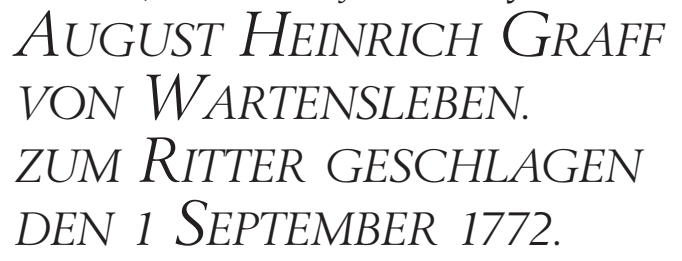

Górna część - większa, wielkości 2/3 pola tablicy, zawiera herb. Tarcza jest podzielona na trzy pola - dwa u góry i jedno u dołu. Górne lewe oraz dolne pole mają tło złote, górne prawe pole - szare. Na środku tarczy mniejsza tarcza z umieszczonym w czarnym polu krzyżem maltańskim, na tle dwugłowego czarnego orła z rozpostartymi skrzydłami. Poniżej w dolnym polu tarczy namalowany krzew, zza którego wybiega zwierzę namalowane czerwoną farba, przypominające psa lub lisa. W klejnocie trzy hełmy z koronami. Środkowy wieńczą dwa rzędy piór i postać stojącego na dwóch tylnych łapach psa lub lisa, lewy - rozpostarte czarne orle skrzydła, prawy wieńczy ucięta na wysokości barku ręka. Na hełmie środkowym są umieszczone czerwone labry ze złotym podbiciem. Labry prawego i lewego hełmu mają czarną barwę i złote podbicie. Tło kompozycji jest wypełnione kolorem różowoczerwonym.

\section{Technika oryginału i analiza sposobu wykonania ${ }^{24}$}

Podobrazie drewniane, sosnowe, bez jakichkolwiek śladów wzmocnienia desek od odwrocia. Deski zostały pocięte maszynowo, o czym świadczy równa powierzchnia przy krawędziach każdej z nich. Deski stanowiące podobrazie zostały sklejone na styk za pomocą kleju kazeinowego. Przed naniesieniem gruntu deski przeklejono klejem glutynowym, a nasteppnie naniesiono bardzo cienką warstwę białej farby emulsji (wypełniacz to biel ołowiowa) stanowiącej rodzaj gruntu. Na tak przygotowanym podobraziu wykonano w technice olejnej przedstawienie herbu, posługując się subtelnymi impastami. Farby nakładano w jednej warstwie, kryjąco, bezpośrednio na warstwę zaprawy.

24 Badania budowy technicznej wykonał A. Nóżka pod kier. T. Ważnego i Z. Rozłuckiej. 
Powierzchnię obrazu zabezpieczono werniksem z żywicy naturalnej. Odwrocie obrazu, jego boki i brzegi w celach ochronnych zamalowano warstwą czerwonej farby olejnej. Na podobrazie nabita jest za pomocą kołków drewnianych rama z drewna sosnowego, o wysokości $1,7 \mathrm{~cm}$ i szerokości $2,5 \mathrm{~cm}$, długość zaś jest odpowiednia do długości boków podobrazia.

\section{Tablica z herbem Georga Albrechta von Brandenburg 25}

Tablica ta powstała w XIX wieku i jest poświęcona margrafowi Brandenburgii Jerzemu Albrechtowi (zob. il. 6-13), który zajmował to stanowisko przez półtora roku od 161426, żył w latach 1591-1615 i pochodził z rodu spokrewnionego z Hohenzollernami. Margrabiowie Brandenburgii (Fryderyk, Ernest, Jerzy Albrecht, Jan Jerzy i Joachim Zygmunt ${ }^{27}$ ) piastowali ten urząd od 1610 do 1625 roku $^{28}$. Maximilian Brikner w swojej pracy poświęconej brandenbursko-pruskim herbom podaje, że dopiero po 1816 roku zaczęto przedstawiać herb Georga Albrechta wraz z joannickim krzyżem (wkomponowanym na środku wielopolowej tarczy - na 5 i 8 polu) ${ }^{29}$.

Tablica jest wykonana na podłożu drewnianym o wymiarach $85,5 \mathrm{~cm} \times$ $\times 63,5 \mathrm{~cm} \times 1,8 \mathrm{~cm}$. Jest podzielona na dwa pola. Dolne pole, stanowiące 2/5 powierzchni, zawiera złotą inskrypcję na czarnym tle. Możliwe jest odczytanie jedynie cześci napisu, gdyż brakuje środkowego fragmentu podobrazia. Wykonany majuskułą napis brzmi:

NO : $221 \ldots 4$

MargG... GEORG AL.

BRECHT... BRANDEN

BURG R... RTE 11/2 JAHR.

25 Prace konserwatorskie wykonał B. Anusiak pod kier. D. Markowskiego i J. Arszyńskiej, Dokumentacja prac konserwatorskich i restauratorskich (nr inw. 1308), Zakład Konserwacji Malarstwa i Rzeźby Polichromowanej UMK w Toruniu, 2007.

26 T. W. Lange, Szpitalnicy, s. 108.

27 M. Brikner, Brandenburgisch Preussische Wappen. Beschichtliche Darstellung seiner Entwickelung seit dem Jahre 1415, Berlin 1895, s. 91-95.

28 Ibidem, s. 96.

29 Ibidem, s. 94. 
Po uzupełnieniu brakujących liter treść napisu brzmi:

NO : $221614^{30}$

MARGGRAF GEORG AL.

BRECHT VON BRANDEN

BURG REGIERTE 11/2 JAHR ${ }^{31}$.

Górna część - większa, wielkości 3/5 pola tablicy, zawiera herb. Wielopolowa tarcza jest podzielona na 12 pól wypełnionych sylwetkami heraldycznych zwierząt - na przemian lwów, gryfów i orłów. W polach pierwszym, trzecim, czwartym i szóstym gryfy stoją naprzeciw siebie. W polach ósmym i jedenastym są zwrócone w prawą stronę. W polu pierwszym gryf czarny na złotym tle w biało-czerwonym obramieniu, w polu trzecim czerwony ze złotymi łapami na zielonym tle, w polach czwartym i ósmym czerwony z czarnymi skrzydłami na białym tle, w polu szóstym czerwony ze złotymi skrzydłami na białym tle, w polu jedenastym czerwony na białym tle, nad krenelażem. W polach drugim, piątym, siódmym i dziewiątym orły. W polu drugim czerwony na białym tle zwrócony w lewo, w polu piątym czarny na złotym tle zwrócony w lewo, w polach siódmym i dziewiątym dwa czarne, ustawione naprzeciw, na białym i złotym tle. W polu dziesiątym liść akantu na czerwonym tle, w polu dwunastym biało-czarna szachownica. Nad częścią pól piątego i ósmego czarna tarcza z białym krzyżem maltańskim. W klejnocie trzy hełmy, dwa po lewej z koronami. Środkowy wieńczą dwa rozpostarte czarne orle skrzydła, hełm po lewej czarne pawie pióra, po prawej biało-czerwone rogi z gryfem. Labry po prawej białe z czerwonym podbiciem, po lewej czerwone z czarnym. Tło kompozycji jest wypełnione złotem.

30 Margraf Georg Albrecht był 22 baliwem (z niemieckiego Herrenmeister) i rządził przez ponad rok - od $1614 \mathrm{r}$.

31 W tłumaczeniu na język polski: nr 22 1614/margraf Georg Albrecht/z rodu brandenburskiego/rządził przez półtora roku. 


\section{Technika oryginału i analiza sposobu wykonania ${ }^{32}$}

Podobrazie drewniane, świerkowe, wykonane z dwóch desek sklejonych ze sobą na styk za pomocą kleju białkowego - kazeiny. Wymiary poszczególnych desek to: $85,5 \mathrm{~cm} \times 34 \mathrm{~cm}$ (lewa deska, rys. 1) i 85,5 cm $\times 29,5 \mathrm{~cm}$ (prawa deska, rys. 2). Grubość desek to $1,8 \mathrm{~cm}$.

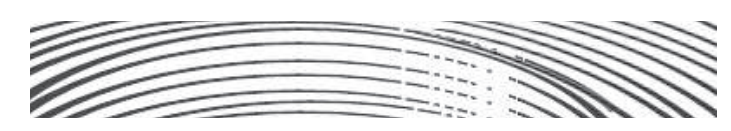

Rys. 1. Przekrój poprzeczny deski lewej (rys. B. Anusiak)

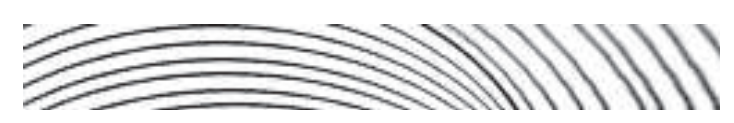

Rys. 2. Przekrój poprzeczny deski prawej (rys. B. Anusiak)

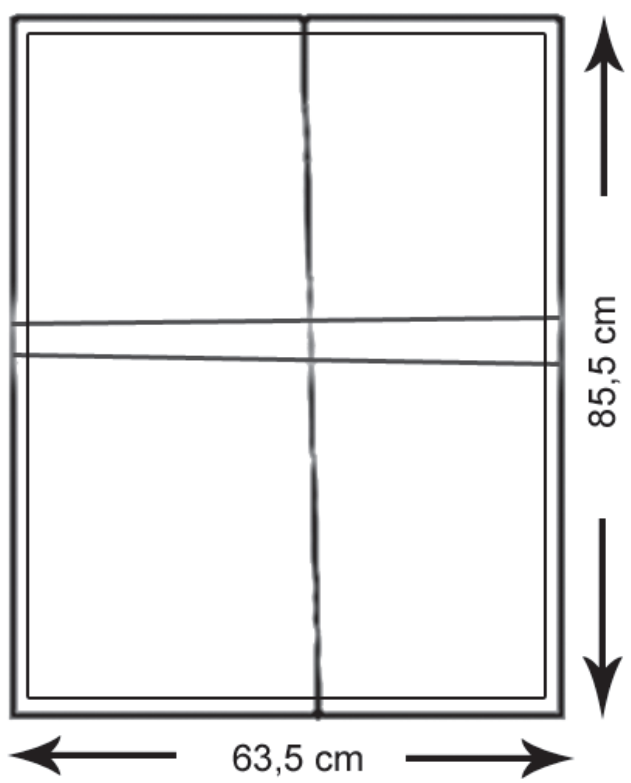

Rys. 3. Rysunek schematyczny podobrazia - widoczne łączenie desek, szponga oraz drewniany profil obramiający lico obiektu (rys. B. Anusiak)

32 Badania budowy technicznej wykonał B. Anusiak pod kier. J. Flika, J. Olszewskiej-Świetlik i M. Górzyńskiej. 


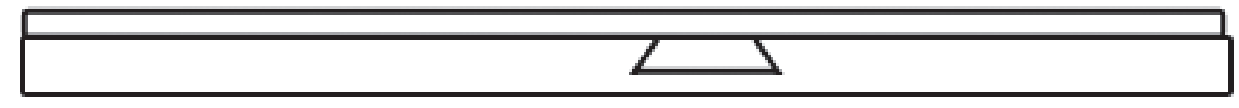

Rys. 4. Rysunek schematyczny podobrazia - widok z boku z widocznym gniazdem szpongi i profilem obramiającym obiekt od strony lica (rys. B. Anusiak)

Deski zostały pocięte maszynowo, o czym świadczy równa powierzchnia przy krawędziach każdej z nich. Dodatkowo odwrocie nosi ślady opracowania z użyciem dłuta (szerokość dłuta - 1,3 mm; profil - półokragły). Podobrazie wzmocniono od odwrocia, przez całą szerokość, poziomą szpongą (wykonaną z drewna świerkowego), wpuszczoną na jaskółczy ogon, w połowie wysokości (rys. 3 i 4). Szponga nieznacznie zwęża się ku końcowi.

Podobrazie zostało przeklejone klejem glutynowym, a następnie zagruntowane cienką warstwą białej zaprawy emulsyjnej (spoiwo: olej i białko, wypełniacz - biel ołowiana).

W tle herbu, na podmalowaniu z czerwieni żelazowej, położono na wytrawę olejną folię miedzianą (analiza spektralna nie wykazała obecności cynku; stwierdzono obecność jedynie miedzi z dodatkiem ołowiu i żelaza). Tła pól herbu, detale z klejnotu (przyłbice, korony) jak również inskrypcje wykonano z folii złotej, o niskiej próbie, z dodatkiem miedzi. Płatki złota kładziono bezpośrednio na warstwe białej zaprawy, na klej glutynowy. Nie stwierdzono obecności pulmentu.

Na tak przygotowanym podłożu wykonano w technice olejnej przedstawienie herbu, posługując się stosunkowo płaskimi impastami. Farby nakładano w jednej warstwie, kryjąco, bezpośrednio na warstwę zaprawy. W partii labrów i w złoconych fragmentach herbu malowano na wcześniej przygotowanych złoceniach. Nie stwierdzono na podstawie przekrojów próbek obecności warstw laserunkowych.

Cała powierzchnię tablicy herbowej zabezpieczono warstwą werniksu z żywicy naturalnej. Odwrocie obrazu, jego boki i brzegi pokryto warstwa czarnej olejnej farby.

Na licu obiektu, przy krawędziach, zamocowano na gwoździe drewniany profil (z drewna sosnowego) - obramienie o półokrągłym przekroju. 


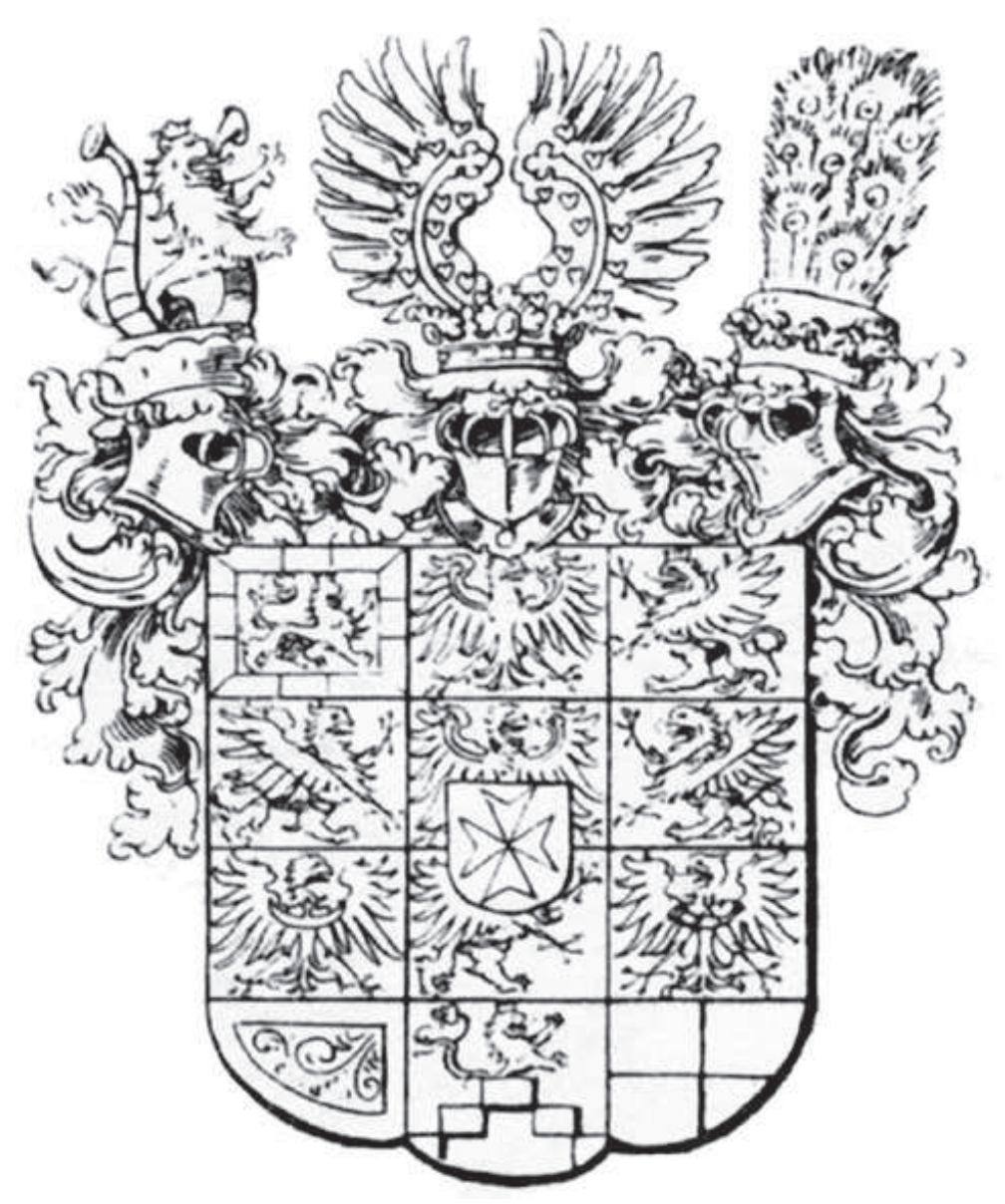

Rys. 5. Herb margrafa Georga Albrechta, za: M. Brikner, Brandenburgisch Preussische Wappen. Beschichtliche Darstellung seiner Entwickelung seit dem Jahre 1415, Berlin 1895, s. 94

\section{Tablica z herbem Friedricha Ludwiga Wilhelma Philippa von Vincke ${ }^{33}$}

Tablica powstała w XIX wieku i jest poświęcona Friedrichowi Ludwigowi Wilhelmowi Philippowi von Vincke (zob. il. 14-15).

Jest wykonana na podłożu drewnianym o wymiarach $70 \mathrm{~cm} \times 50,5 \mathrm{~cm}$ i grubości desek $1,1 \mathrm{~cm}$. Jest podzielona na dwa pola. Dolne pole, stanowiące

33 Prace konserwatorskie wykonuje S. Smagłowski pod kier. D. Markowskiego i J. Arszyńskiej. Tablica wpisana jest do księgi inwentarzowej ZKMiRzP UMK pod numerem 1310. 
1/3 powierzchni, zawiera złota, ozdobną inskrypcję umieszczoną na czarnym tle. Możliwe jest odczytanie jedynie części napisu, gdyż z lewej strony brakuje dwóch fragmentów podobrazia. Wykonany napis brzmi:

...RR F...IEDRICH LUDWIG

...HEL... PHILPP V: VINCKE

...NVE...TIRET DEN

...EN IULIUS 1795.

Po zrekonstruowaniu treść napisu jest następująca ${ }^{34}$ :

HERR FRIEDRICH LUDWIG

WILHELM PHILPP V: VINCKE

INVESTIRET DEN

15-TEN IULIUS 1795.

Górna, większa część, stanowiąca 2/3 pola tablicy, zawiera herb. Tarcza herbowa jest podzielona na cztery pola wypełnione na przemian umieszczonym na czarnym tle krzyżem joannickim (lewe górne i prawe dolne pole) oraz umieszczonym na białym tle (prawe górne i lewe dolne pole tarczy), namalowanym kolorem czerwonym symbolem topora. Tarczę wieńczy hełm umieszczony na osi symetrii, na którym spoczywa zawój (tortillon). Klejnot to siedem pawich piór wychodzących z zawoju, na których namalowano również symbol topora. Ze szczytu hełmu i zza niego wychodzą rozchodzące się w dół białe labry z czerwonym podbiciem. Tło kompozycji jest wypełnione kolorem różowym.

\section{Technika oryginału i analiza sposobu wykonania ${ }^{35}$}

Podobrazie drewniane, sosnowe, wykonane z dwóch sklejonych ze sobą na styk desek (za pomocą kleju kazeinowego). Deski zostały pocięte maszynowo, o czym świadczy równa powierzchnia oraz równe krawędzie każdej z nich. Podobrazie zostało przeklejone klejem glutynowym, a następnie

34 C. Mund, Alfabetisch geordnetes verzeichnis der in der Johannites-ordens-kirche zu Sonnenburg für handenen Wappen-tafeln: nebst historischen und genealogischen Anmerkungen, Küstrin 1869.

35 Badania budowy technicznej wykonał S. Smagłowski pod kier. T. Ważnego, J. Olszewskiej-Świetlik i M. Górzyńskiej. 
zagruntowane cienką warstwą różowej zaprawy emulsyjnej (biel ołowiana, cynober i czerwień żelazowa jako wypełniacz, klej glutynowy i olej jako spoiwo) w formie przecierki. Na tak przygotowanym podłożu wykonano farbami olejnymi przedstawienie herbu, posługując się stosunkowo płaskimi impastami. Farba została nałożona w dwóch warstwach. Pierwsza, kryjąca, o płaskich impastach, nakładana bezpośrednio na warstwę zaprawy, podmalowanie pól tarczy herbowej, hełm oraz światłocieniowe labry i pawie pióra wychodzace z czerepu hełmu. W ten sposób wykonano podstawowy rysunek herbu. Druga warstwa malarska jest laserunkowa. Wykonano nią precyzyjny rysunek i detale.

Dolna czesść tablicy to czarne tło namalowane czernią roślinną bezpośrednio na różowej zaprawie, na które następnie naniesiono warstwę podkładową pod złoconą inskrypcję olejną, tzw. „złotą farbę” (czerwień żelazowa $\mathrm{Fe}_{2} \mathrm{O}_{3}$, biel ołowiana $2 \mathrm{PbCO}_{3} \times \mathrm{Pb}(\mathrm{OH})_{2}$, ugier $\mathrm{Fe}(\mathrm{OH})_{3}$, spoiwo olejne). Inskrypcję oraz złocenia na profilu wykonano złotem płatkowym na wyżej wymienioną „złotą farbę”. Boki i krawędzie tablicy pomalowano czernią roślinną w spoiwie olejnym. Na zakończenie cała powierzchnię tablicy herbowej zabezpieczono warstwą werniksu autorskiego z żywicy naturalnej z dodatkiem oleju.

Na licu tarczy, przy krawędziach, zamocowano na drewniane kołeczki dekoracyjny drewniany profil, przyklejając go dodatkowo klejem kazeinowym. Jego wewnętrzna część została pozłocona w technice takiej jak inskrypcje.

\section{Tablica z herbem Wilhelma Christiana Gottloba von Pöllnitz ${ }^{36}$}

Tablica ta, tak jak pozostałe, powstała w XIX wieku. Jest poświęcona osobie Wilhelma Christiana Gottloba von Pöllnitz (zob. il. 16-17).

Wykonano ją na podłożu drewnianym o wymiarach $68,5 \mathrm{~cm} \times 38 \mathrm{~cm}$ i grubości desek $2,2 \mathrm{~cm}$. Jest podzielona na dwa pola. Dolne pole, stanowiące $1 / 3$ powierzchni, zawiera złota, ozdobną inskrypcję umieszczoną na

36 Prace konserwatorskie wykonuje S. Smagłowski pod kier. D. Markowskiego i J. Arszyńskiej. Tablica wpisana jest do ksieggi inwentarzowej ZKMiRzP UMK pod numerem 1309. 
czarnym tle. Możliwe jest odczytanie jedynie cześci napisu, gdyż brakuje prawego fragmentu podobrazia. Wykonany napis brzmi:

HERR WiLHELM CHRISTIA...

LOB VON PÖLLNITZ.

WARD ZUM RITTER GES...

GEN DEN $i$ : OCTOBER ...

Po zrekonstruowaniu treść napisu jest następująca ${ }^{37}$ :

Herr Wilhelm Christian GotT-

LOB VON PÖLLNITZ.

WARD ZUM RITTER GESCHLA-

GEN DEN i: OCTOBER 1764.

Górna część - większa, wielkości 2/3 pola tablicy, zawiera herb. Tarcza jest podzielona na cztery pola wypełnione na przemian umieszczonym na czarnym tle krzyżem joannickim i umieszczonym na tle białym, namalowanym kolorem niebieskim, symbolem krokwi. Na szczycie tarczy, na osi symetrii jest hełm, zwieńczony klejnotem w formie dwóch trąb. Ze szczytu hełmu i zza niego wychodzą rozchodzące się w dół białe labry z błękitnym podbiciem. Tło kompozycji jest wypełnione kolorem ciemnoróżowym.

\section{Technika oryginału i analiza sposobu wykonania ${ }^{38}$}

Podobrazie drewniane, sosnowe, pierwotnie było wykonane z dwóch sklejonych ze sobą na styk desek (za pomocą kleju białkowego - kazeiny). Deski zostały pocięte stycznie, maszynowo, o czym świadczy równa powierzchnia przy krawędziach każdej z nich. Podobrazie zostało przeklejone klejem glutynowym, a następnie zagruntowane cienką warstwą różowej zaprawy emulsyjnej (biel ołowiana i czerwień żelazowa jako wypełniacz, klej glutynowy i olej jako spoiwo).

37 C. Mund, op. cit.

38 Badania budowy technicznej wykonał S. Smagłowski pod kier. T. Ważnego, J. Olszewskiej-Świetlik i M. Górzyńskiej. 
Na tak przygotowanym podłożu namalowano w technice olejnej przedstawienie herbu, posługując się stosunkowo płaskimi impastami. Farby nakładano w jednej warstwie, kryjąco, bezpośrednio na warstwę zaprawy. Dolna cześć tablicy to czarne tło z czerni roślinnej namalowanej bezpośrednio na różowej zaprawie, na której następnie wykonano podkładową warstwę olejną, tzw. „złotą farbe" (czerwień żelazowa $\mathrm{Fe}_{2} \mathrm{O}_{3}$, biel ołowiana $2 \mathrm{PbCO}_{3} \times$ $\times \mathrm{Pb}(\mathrm{OH})_{2}$, ugier $\mathrm{Fe}(\mathrm{OH})_{3}$, spoiwo olejne, olej w reakcji z $2 \mathrm{nNaOH}$ rozpuszczał sie), pod złocenia. Złocone inskrypcje oraz złocenia na profilu wykonano złotem płatkowym na wyżej wymienioną tzw. „złotą farbę”. Na licu tarczy, przy krawędziach, zamocowano na klej kazeinowy dekoracyjny drewniany profil, dodatkowo mocując go na kołeczki drewniane. Cała powierzchnię tablicy herbowej zabezpieczono warstwą werniksu z żywicy naturalnej z dodatkiem oleju. Boki i odwrocie pokryto warstwą różowej zaprawy emulsyjnej, takiej jak na licu.

\section{Prace konserwatorsko-restauratorskie}

Niestety, brakuje dokładnych danych na temat przechowywania obiektów przed konserwacją.

We wszystkich przypadkach podobrazia były połamane na mniejsze części. Trzy z czterech tablic nie były zachowane w całości, najczęstszym zniszczeniem były braki części drewna - podobrazia oraz drewnianego obramowania. Czwarta tablica, z herbem Georga Albrechta von Brandenburg, miała mniejsze ubytki, ale większe zniszczenia o charakterze mechanicznym. We wszystkich obiektach zaobserwowano w drewnianym podobraziu wyraźne ślady żerowania owadów, których intensywna działalność w niektórych przypadkach znacznie wpłynęła na obniżenie właściwości mechanicznych podłoża. Stwierdzono również typowe zmiany starzeniowe, i to zarówno w warstwie malarskiej, jak i zżółkniętej warstwie werniksu.

Założeniem prac konserwatorskich było przywrócenie pierwotnego wyglądu tablic. W większości z nich konieczne było uzupełnienie brakujących części podobrazia i obramienia oraz wzmocnienie konstrukcyjne podłoża. W dalszej kolejności przewidywano wykonanie czynności restauratorskich, najczęściej polegających na uzupełnieniu ubytków warstwy malarskiej 
w obrębie oryginału oraz wykonaniu rekonstrukcji brakującego fragmentu tarczy na uzupełnionym fragmencie podobrazia. Przed przystapieniem do prac konserwatorskich przeprowadzono badania technologii, które pozwoliły określić szczegółowo technikę namalowania tablic. Najogólniej można stwierdzić, że zostały one wykonane przy końcu XIX wieku techniką wykonania mającą naśladować tarcze XVI-wieczne, stąd zapewne świadome zastosowanie w wielu przypadkach warstwy patynującej, założonej na powierzchnię warstwy malarskiej. Jak już wspomniano, podłożem do namalowania tarcz herbowych było podobrazie drewniane składające się najcześciej z kilku desek, sklejonych ze sobą. Przygotowując podobrazie, jednocześnie wykonywano obramienie, które za pomocą drewnianych kołków było mocowane od strony lica. Po założeniu warstwy przeklejenia z kleju glutynowego zakładano na powierzchnię zaprawę albo bezpośrednio cienką warstwę barwną - rodzaj przecierki lub folię miedzianą, na których to warstwach wykonywano opracowanie malarskie - malowano herb oraz wykonywano inskrypcje. Warstwa barwna lub folia miedziana stanowiły najczęściej tło dla namalowanego herbu. Po wykonaniu opracowania malarskiego na całość powierzchni nałożono wspomnianą już warstwę barwionego lakieru, ciemnobrązowego, patynującego powierzchnię lica.

Prace konserwatorsko-restauratorskie miały na celu powstrzymanie procesów niszczących oraz przede wszystkim przywrócenie obiektom pełnej wartości ekspozycyjnej. W pierwszej kolejności oczyszczono odwrocie i lico obrazów z zabrudzeń powierzchniowych. Ze względu na wyraźne zmiany tonalne werniksu, negatywnie wpływające na kolorystykę oryginalnego opracowania malarskiego w trzech z konserwowanych tablic (wyjątkiem była tablica z herbem Augusta Heinricha Graffa von Wartensleben), usunięto z lica pożólknięty werniks. W przypadku tablicy z herbem Friedricha Ludwiga Wilhelma Philippa von Vincke i tablicy z herbem Wilhelma Christiana Gottloba von Pöllnitz był to zabieg w dużej części wykonany mechanicznie, polegający na ścienieniu werniksu. Każda inna metoda była niebezpieczna, gdyż groziła rozmiękczeniem warstw spodnich i powstaniem przetarć oryginału warstwy malarskiej. Ważnym etapem prac konserwatorskich było zrekonstruowanie brakujących fragmentów drewnianego podobrazia oraz listew obramienia. We wszystkich przypadkach przeprowadzono impregnacje strukturalną całych podobrazi lub ich zniszczonych partii (tablica z herbem Augusta 
Heinricha Graffa von Wartensleben). Brakujące fragmenty desek podobrazia wycięto z wysezonowanych desek świerkowych lub sosnowych, które opracowywano za pomocą dłuta. Drewniane fleki zaimpregnowano 20\% roztworem paraloidu B 72 w toluenie. Uzupełnienia wraz z oryginalnymi częściami sklejono żywicą epoksydową Araldit. W przypadku tablicy z herbem Augusta Heinricha Graffa von Wartensleben dodatkowo zastosowano łączenie na kotki drewniane. Pozostałe mniejsze fragmenty ubytków drewna uzupełniono kitem na bazie żywicy Araldit. Niezachowane elementy drewnianych profili obramiających lica obiektów wykonano z drewnianych, profilowanych listew i przymocowano do podłoża.

Ubytki w większych partiach złoceń uzupełniano złotem płatkowym położonym na mikstion (tablica $\mathrm{z}$ herbem Georga Albrechta von Brandenburg) lub na klej glutynowy (tablica z herbem Augusta Heinricha Graffa von Wartensleben). Drobniejsze ubytki, w tym głównie partie złoconych inskrypcji, uzupełniano złotem proszkowym w 2\% wodnym roztworze polialkoholu winylu. Dla uzyskania odpowiedniego odcienia do spoiwa dodawano akwarel Rembrandt firmy Talens.

W tablicy z herbem Georga Albrechta von Brandenburg rekonstruowane złocenia w partii tarczy dodatkowo scalono optycznie z partiami oryginalnych złoceń za pomocą olejnego laserunku.

Przed przystapieniem do prac restauratorskich w wielu partiach konieczne było wykonanie charakterystycznej faktury powierzchni. Do tego celu użyto żelu akrylowego do impastów nakładanego na powierzchnię pędzlem, po rozcieńczeniu.

Ubytki warstwy malarskiej uzupełniano z zastosowaniem farb akwarelowych i akrylowych. W tablicy z herbem Georga Albrechta von Brandenburg ubytki folii miedzianej w tle kompozycji uzupełniono proszkiem miedzianym (produkt firmy Maimeri). Miejsca wykonania uzupełnień uprzednio podmalowano akrylową czerwienią żelazową Rembrandt firmy Talens.

Następnie na powierzchnię lica wszystkich konserwowanych tarcz założono warstwę werniksu ochronnego. Odwrocia obiektów wraz z częściami sztorcowymi desek podobrazia zabezpieczono przed wilgocią warstwą wosku bielonego z damarą (w proporcjach 1:1).

Prace konserwatorskie przy dwóch z czterech konserwowanych tablic: z herbem Georga Albrechta von Brandenburg i z herbem Augusta Heinricha 
Graffa von Wartensleben zostały zakończone, a obiekty przekazane właścicielowi. Efekty ich prezentują dołączone do artykułu fotografie tablic po konserwacji. Tablica $\mathrm{z}$ herbem Friedricha Ludwiga Wilhelma Philippa von Vincke i tablica z herbem Wilhelma Christiana Gottloba von Pöllnitz stanowią nadal przedmiot prac konserwatorskich, a ich zakończenie planowane jest na połowę 2010 roku. 


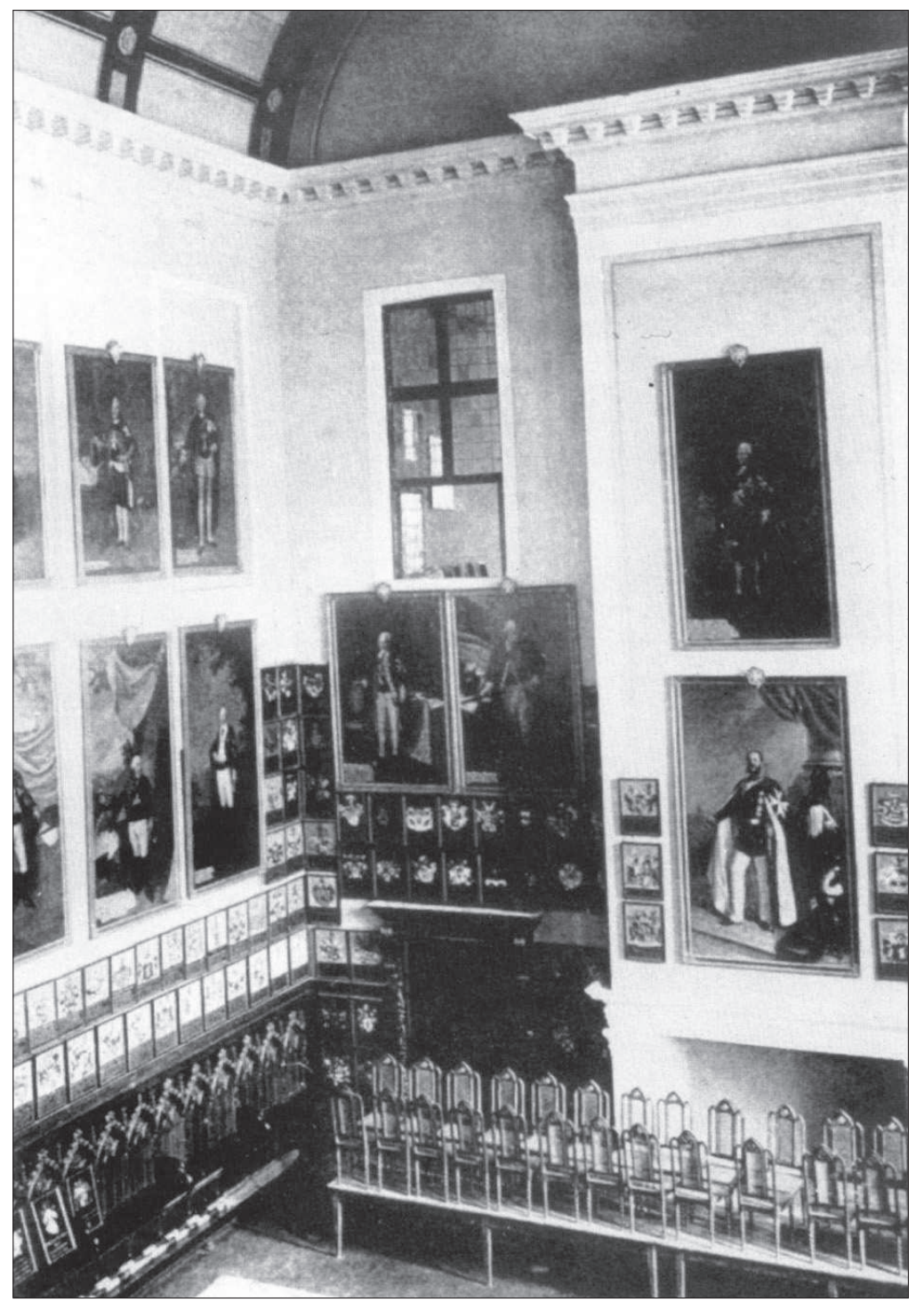

Il. 1. Wnętrze sali reprezentacyjnej zamku w Słońsku, za: T. W. Lange, Szpitalnicy. Joannici. Kawalerowie maltańscy, Warszawa 1999, fot. 25

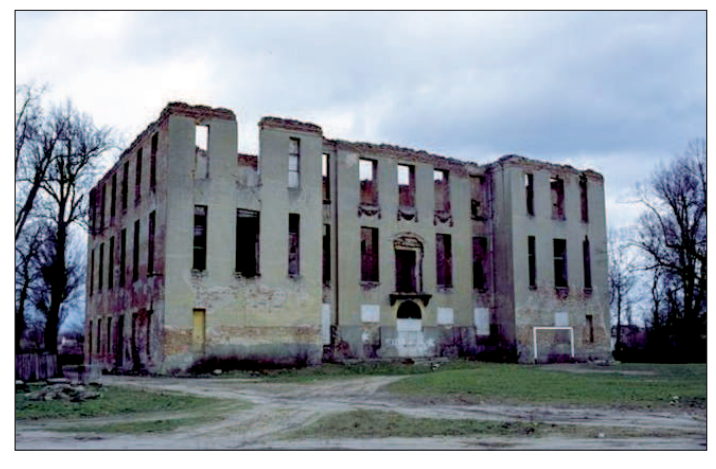

Il. 2. Zamek w Słońsku - stan obecny, http://www.zamki.pl 


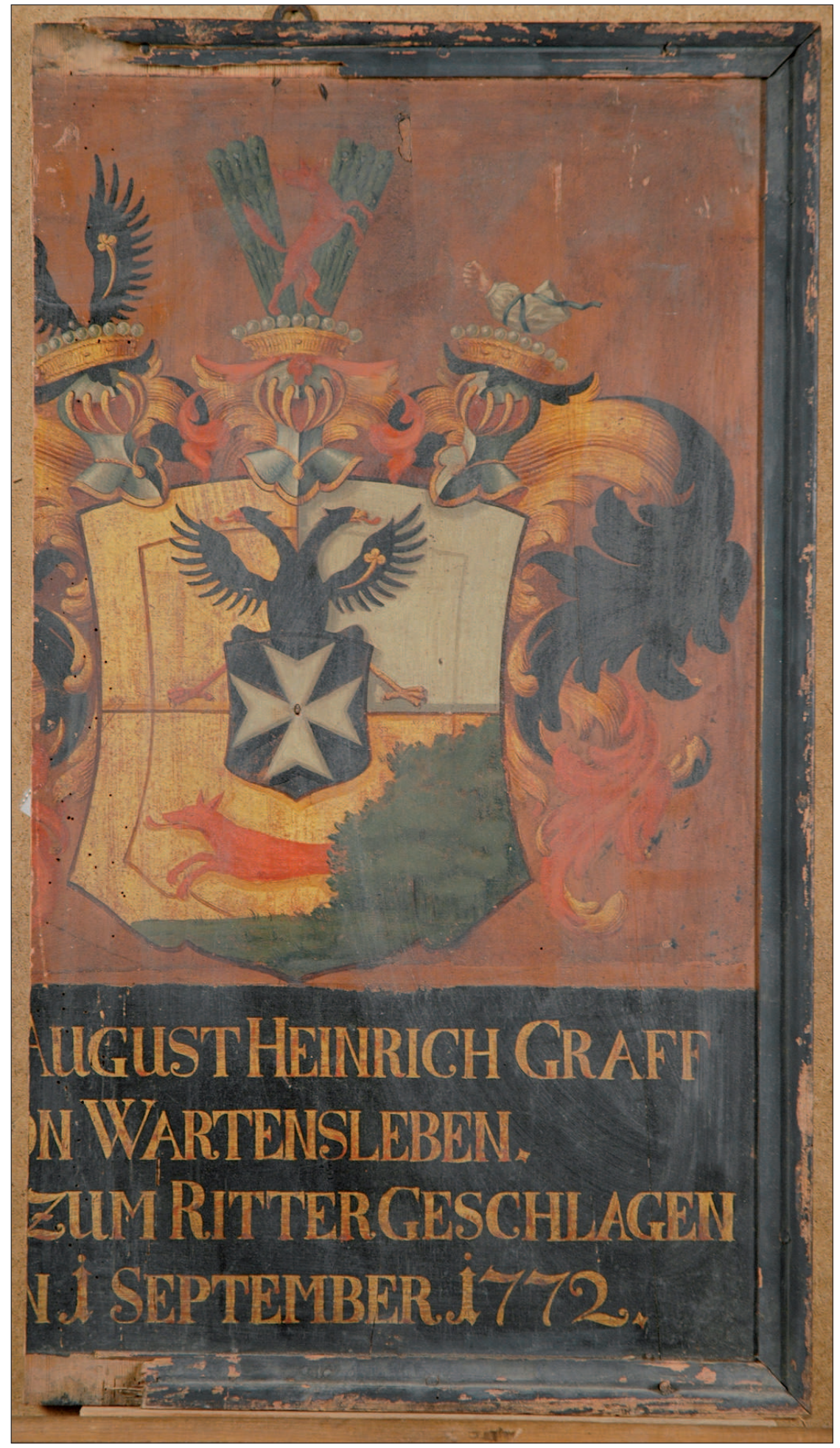

Il. 3. Lico tablicy z herbem Augusta Heinricha Graffa von Wartensleben przed konserwacją. Na zdjęciu widoczny ubytek lewej cześci podobrazia (fot. A. Nóżka) 


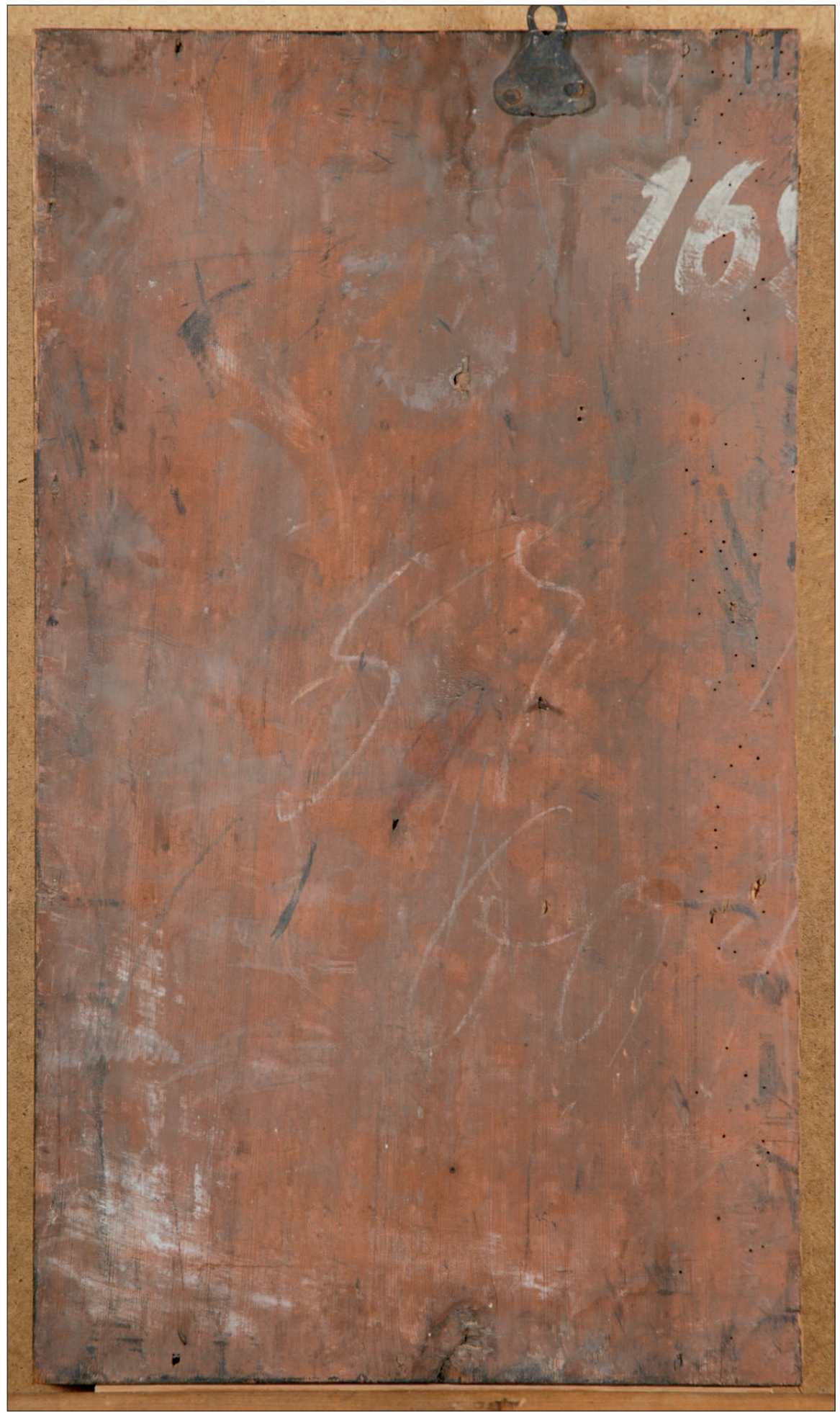

Il. 4. Odwrocie tablicy z herbem Augusta Heinricha Graffa von Wartensleben przed konserwacja. Oprócz ubytku podobrazia widoczne otwory wylotowe po żerowaniu owadów (fot. A. Nóżka) 


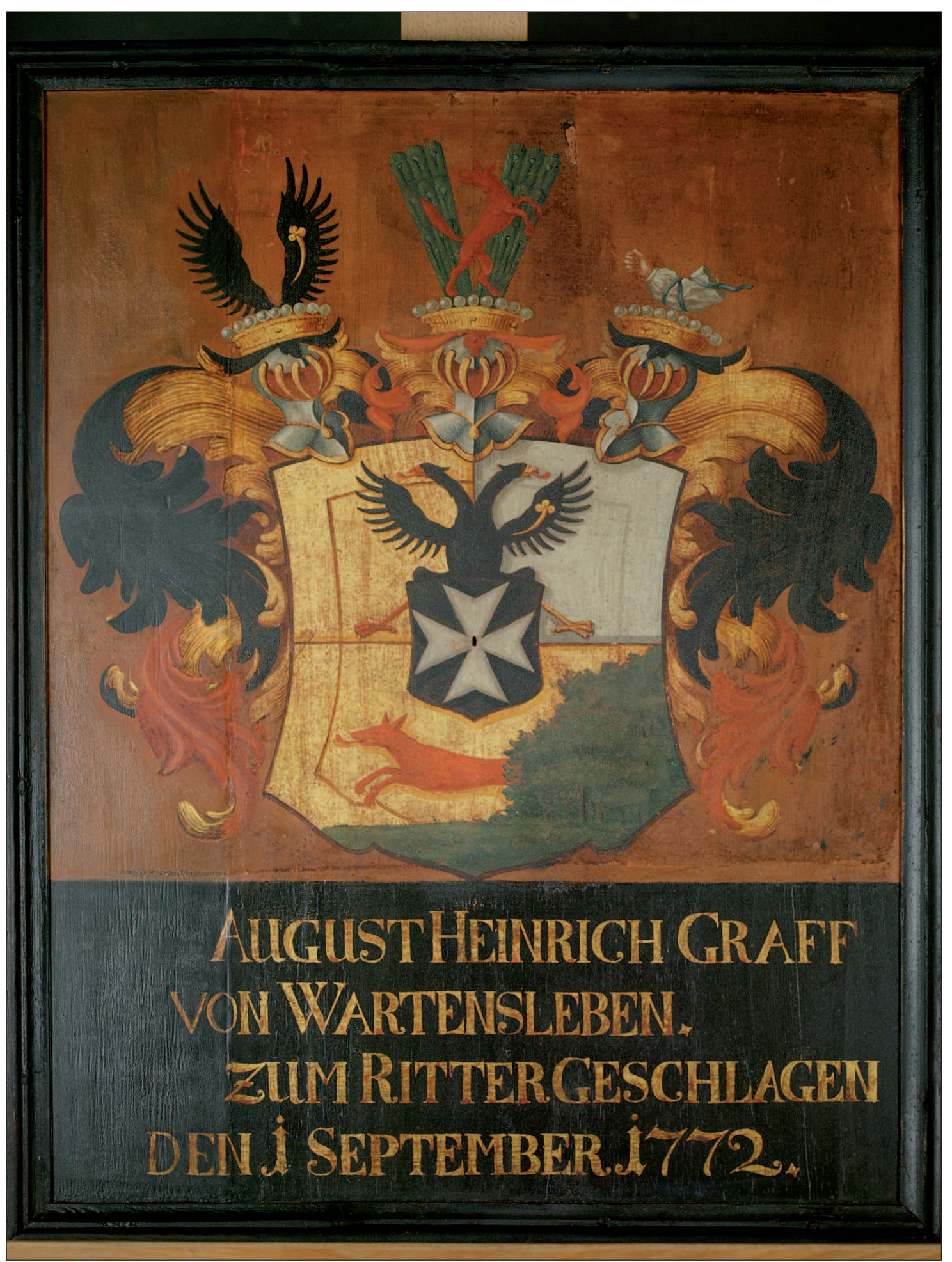

Il. 5. Lico tablicy z herbem Augusta Heinricha Graffa von Wartensleben po konserwacji (fot. A. Nóżka) 


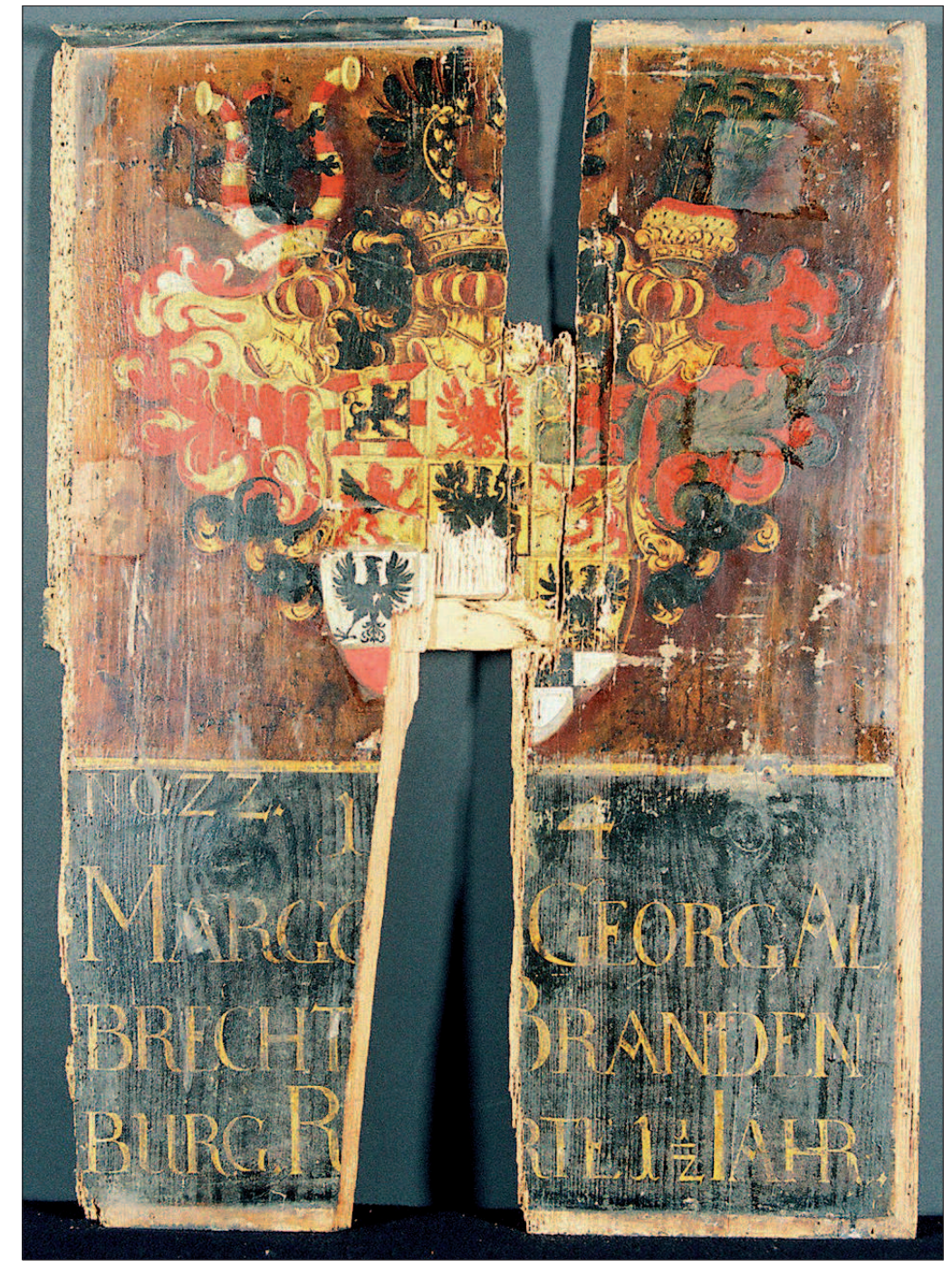

Il. 6. Lico tablicy z herbem Georga Albrechta von Brandenburg przed konserwacją (fot. B. Anusiak) 


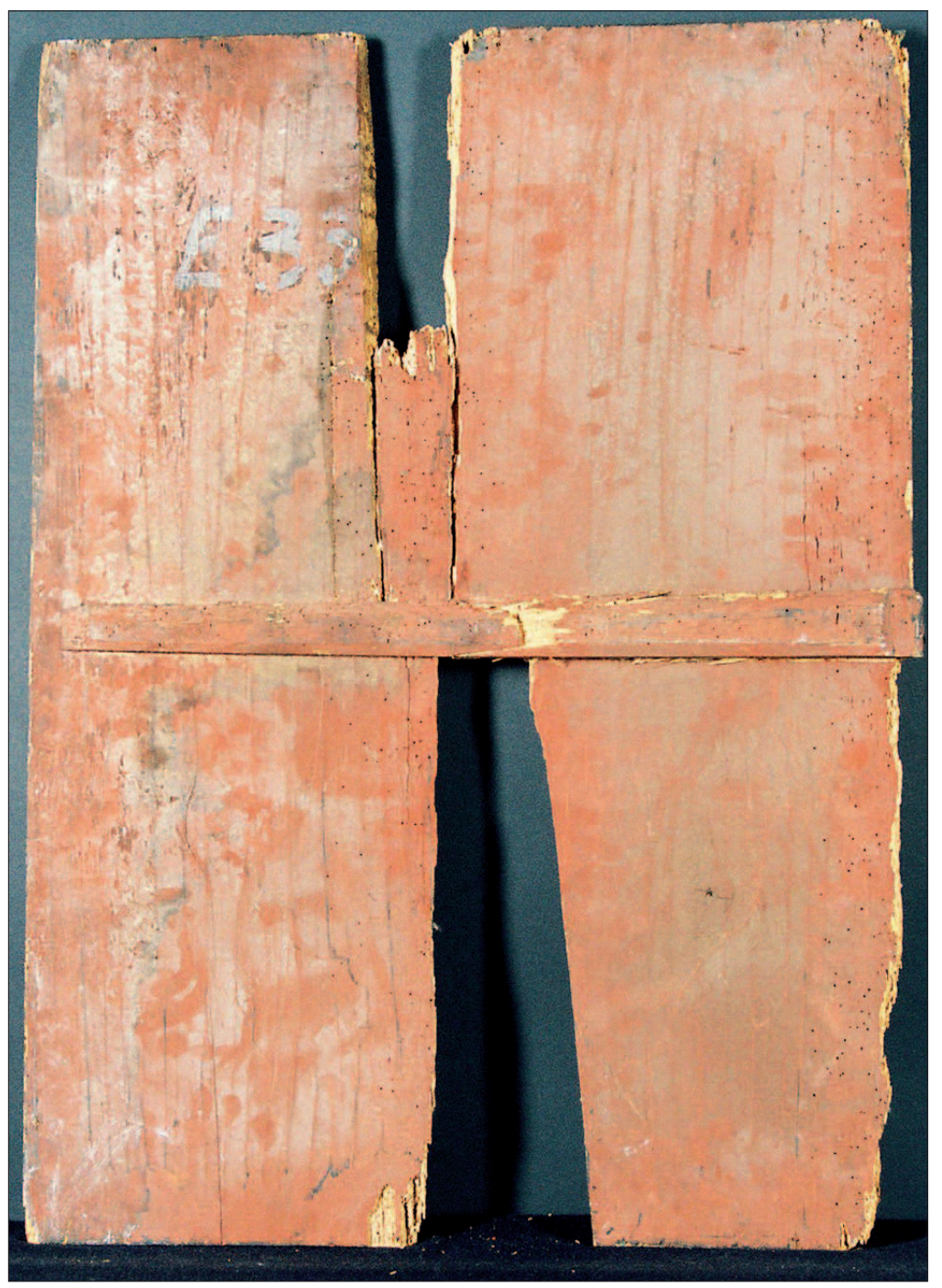

Il. 7. Odwrocie tablicy z herbem Georga Albrechta von Brandenburg przed konserwacją (fot. B. Anusiak) 


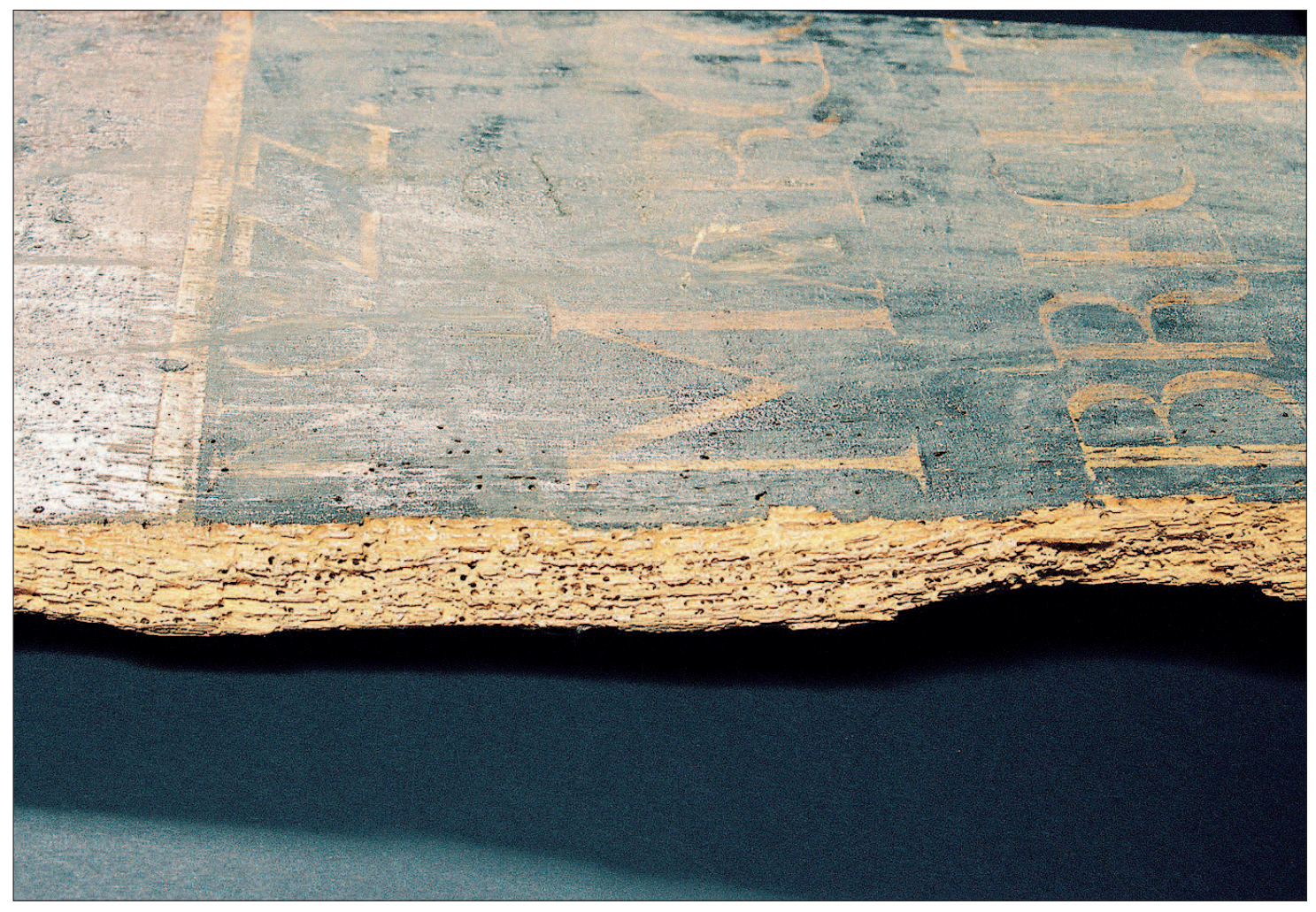

Il. 8. Fragment lica tablicy z herbem Georga Albrechta von Brandenburg przed konserwacją. Na zdjęciu widoczna zniszczona przez owady krawędź deski (fot. B. Anusiak) 


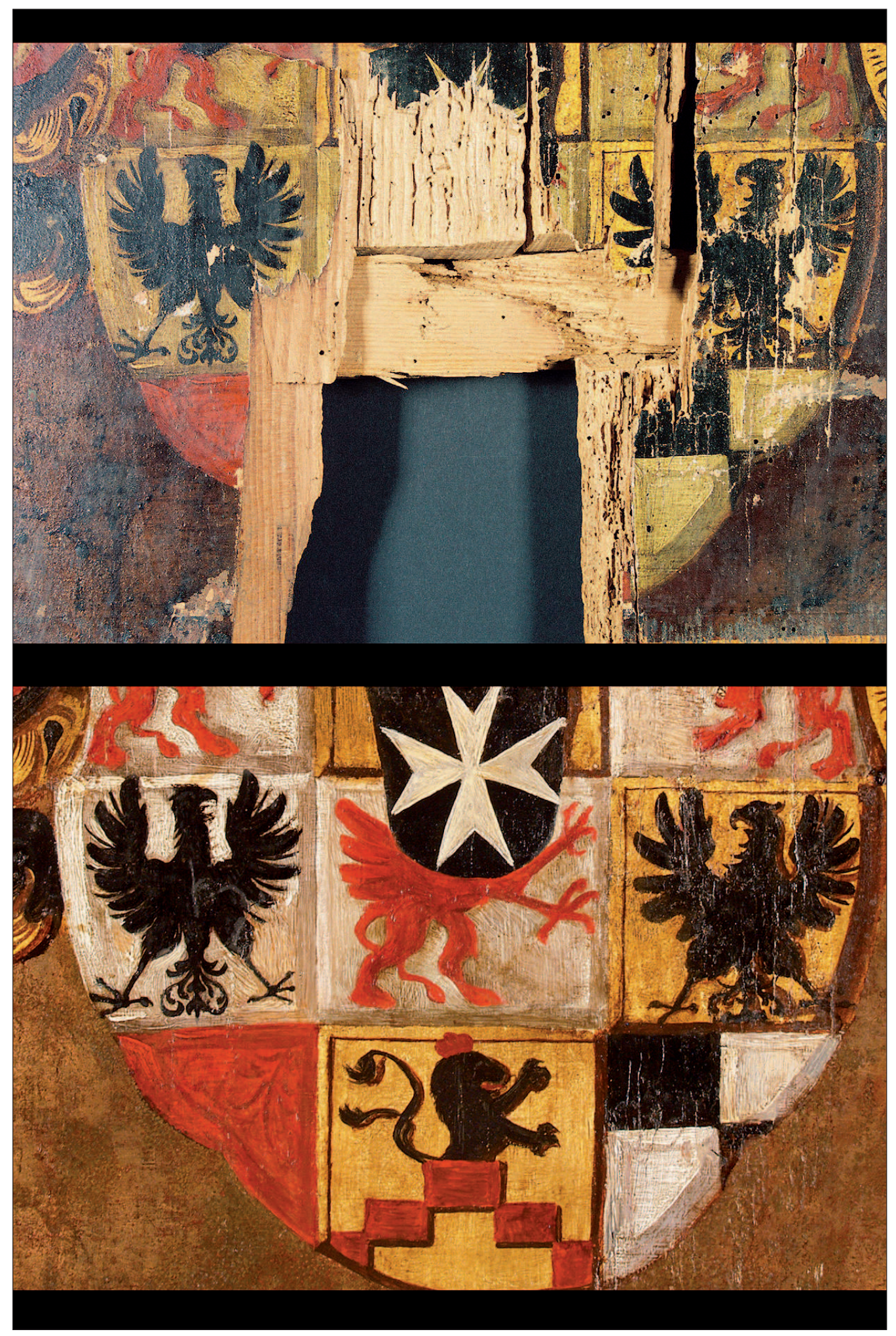

I1. 9, 10. Fragmenty lica tablicy z herbem Georga Albrechta von Brandenburg przed konserwacją i po konserwacji (fot. B. Anusiak) 


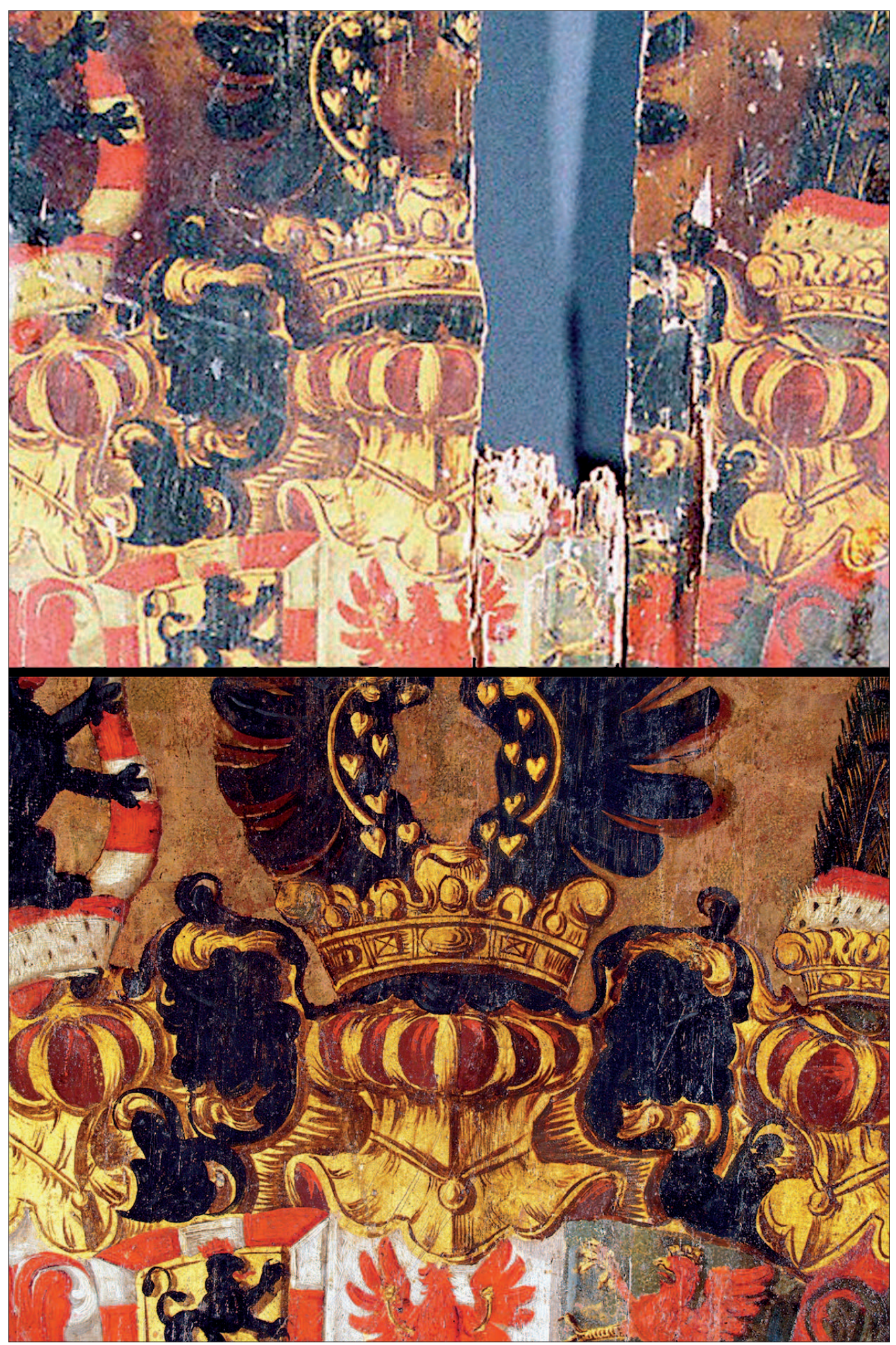

Il. 11, 12. Fragmenty lica tablicy z herbem Georga Albrechta von Brandenburg przed konserwacją i po konserwacji (fot. B. Anusiak) 


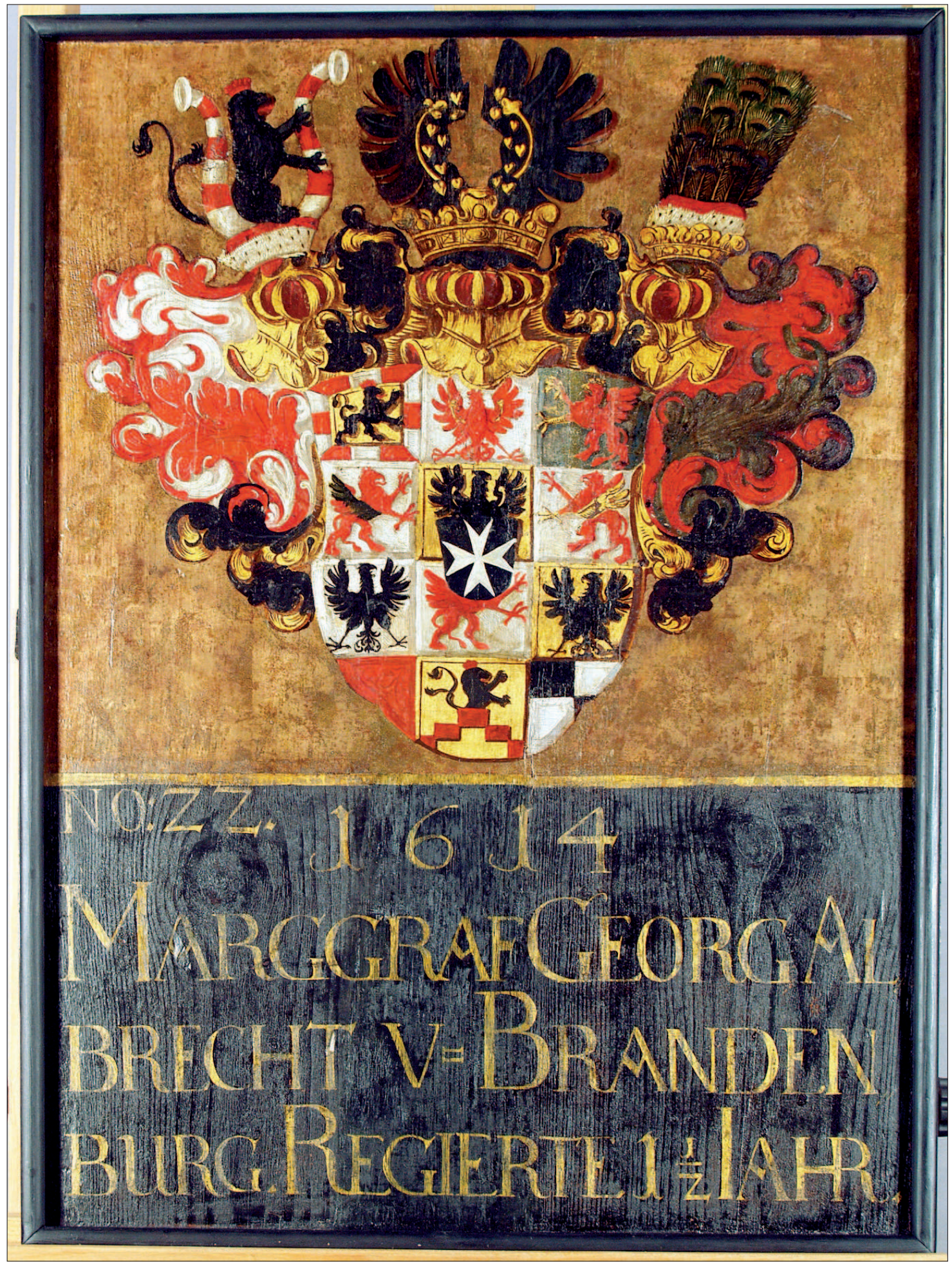

Il. 13. Lico tablicy z herbem Georga Albrechta von Brandenburg po konserwacji (fot. B. Anusiak) 


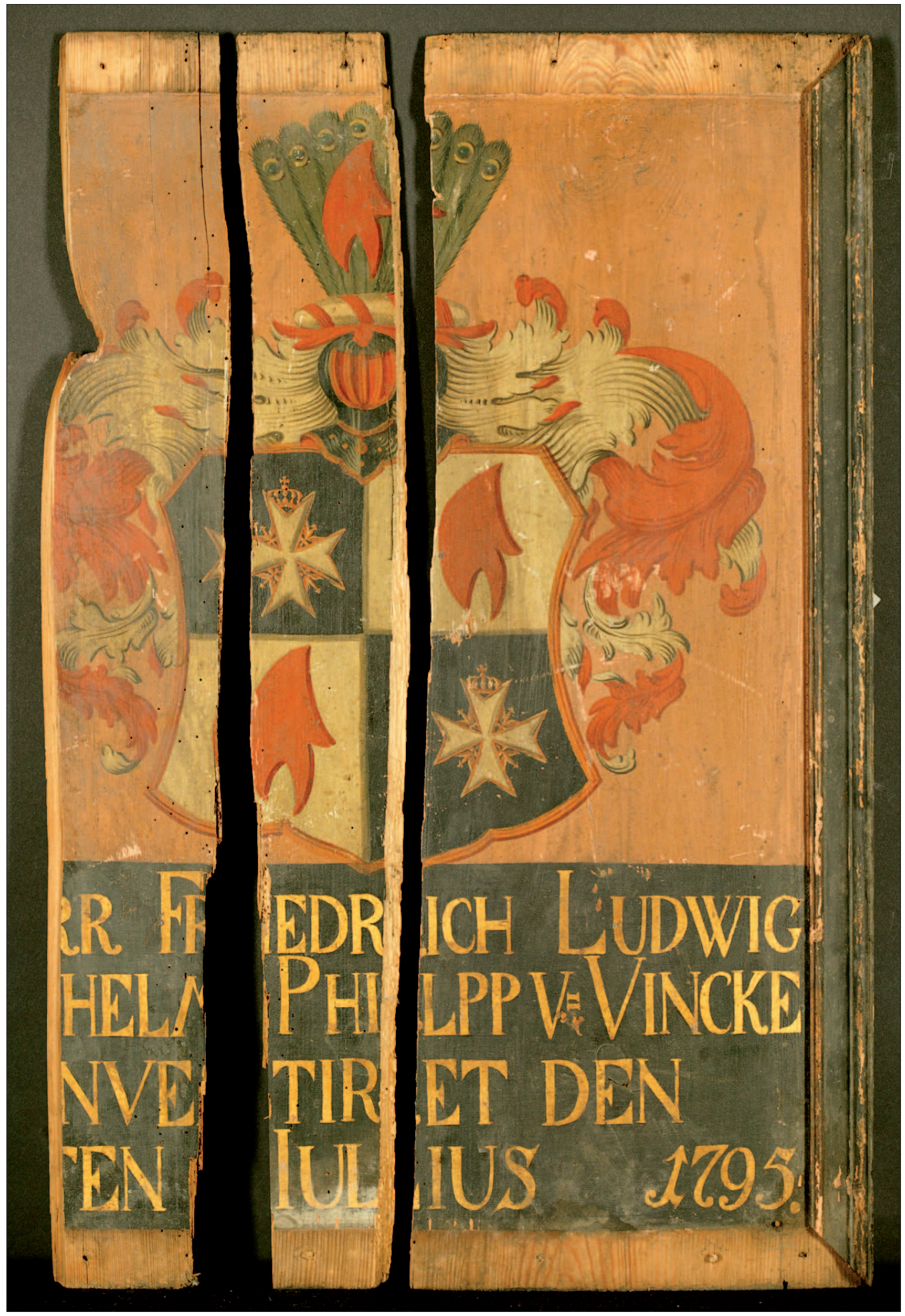

Il. 14. Lico tablicy z herbem Friedricha Ludwiga Wilhelma Philippa von Vincke przed konserwacją (fot. S. Smagłowski) 


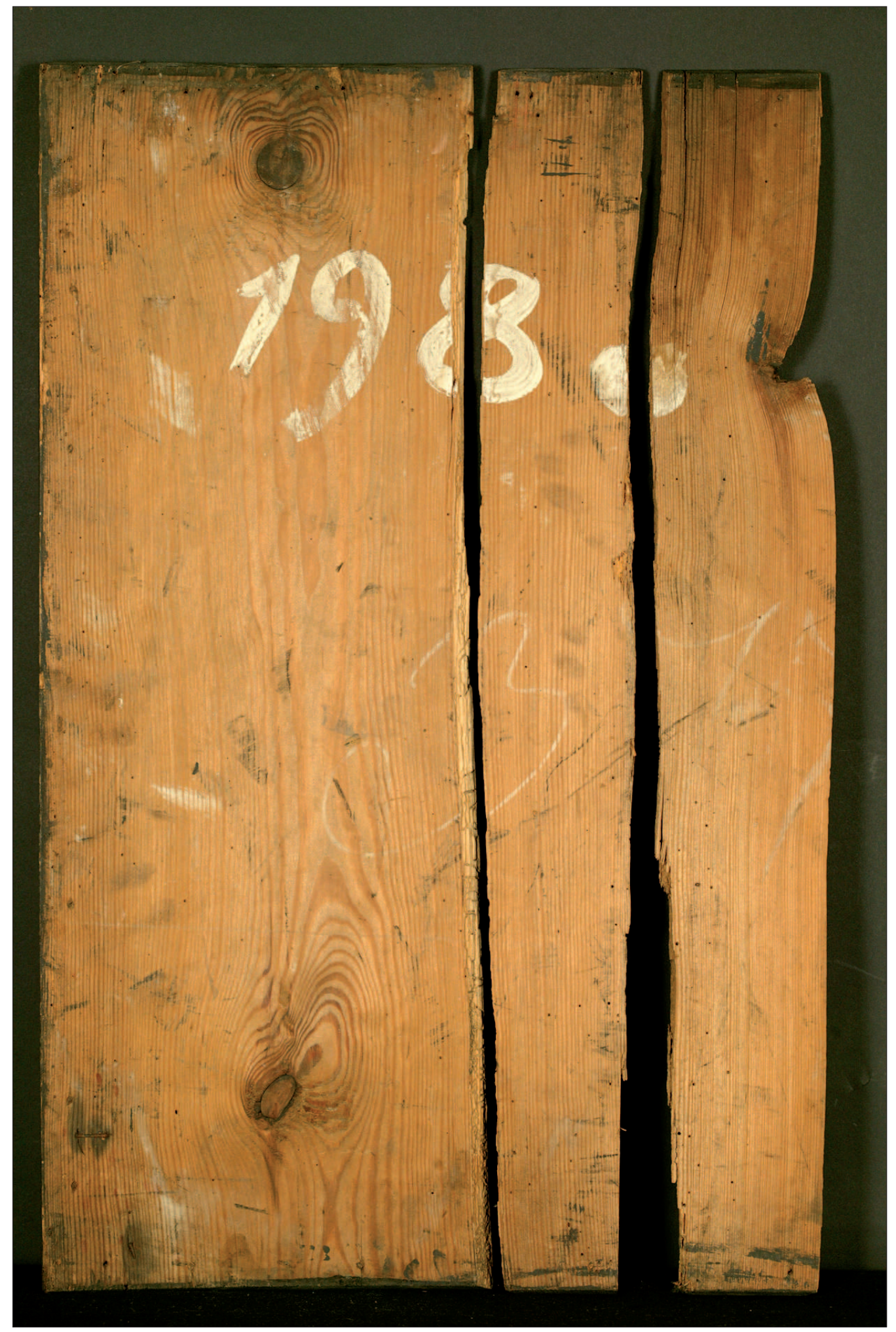

I1. 15. Odwrocie tablicy z herbem Friedricha Ludwiga Wilhelma Philippa von Vincke przed konserwacją (fot. S. Smagłowski) 


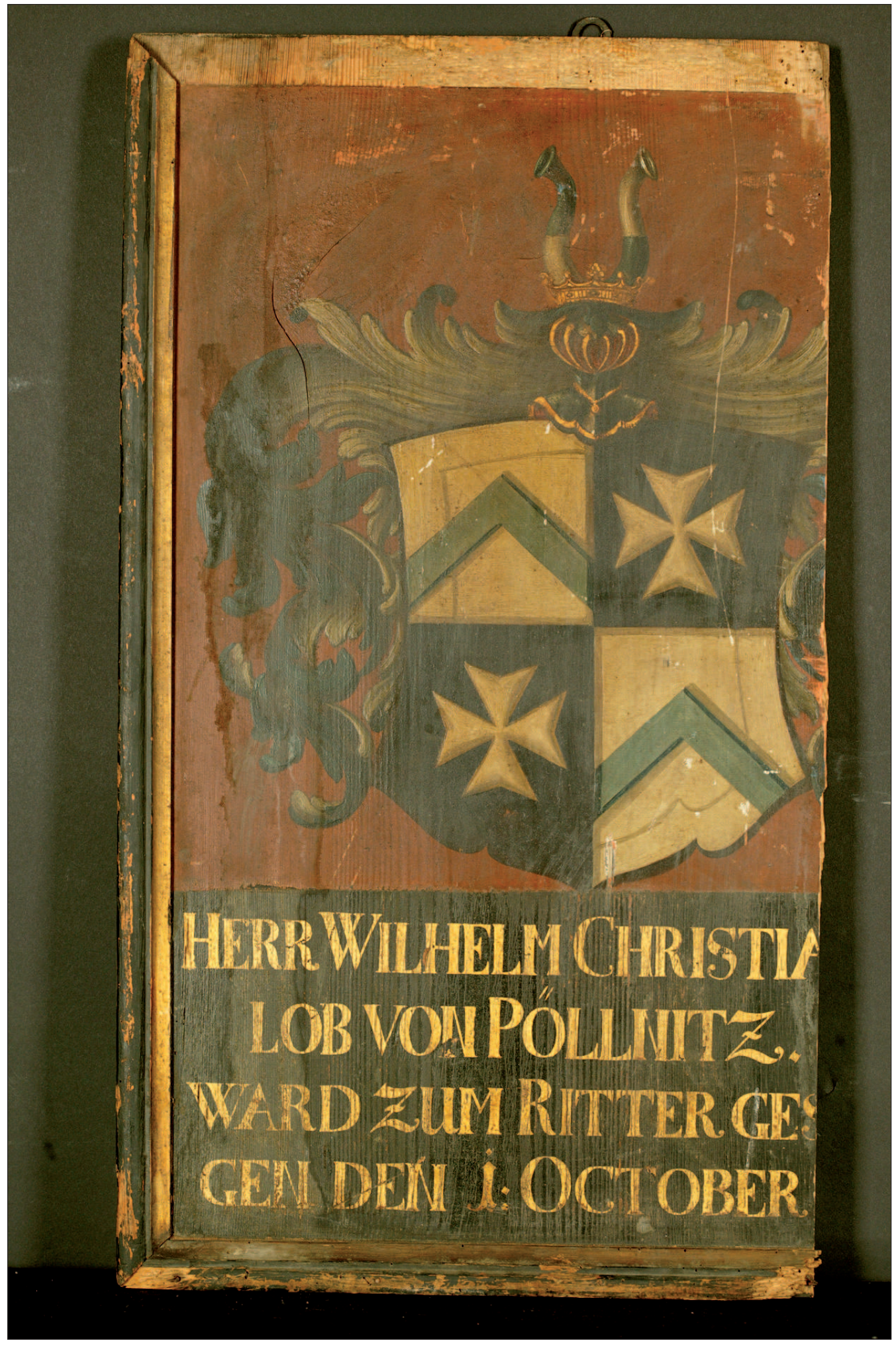

Il. 16. Lico tablicy z herbem Wilhelma Christiana Gottloba von Pöllnitz przed konserwacją (fot. S. Smagłowski) 


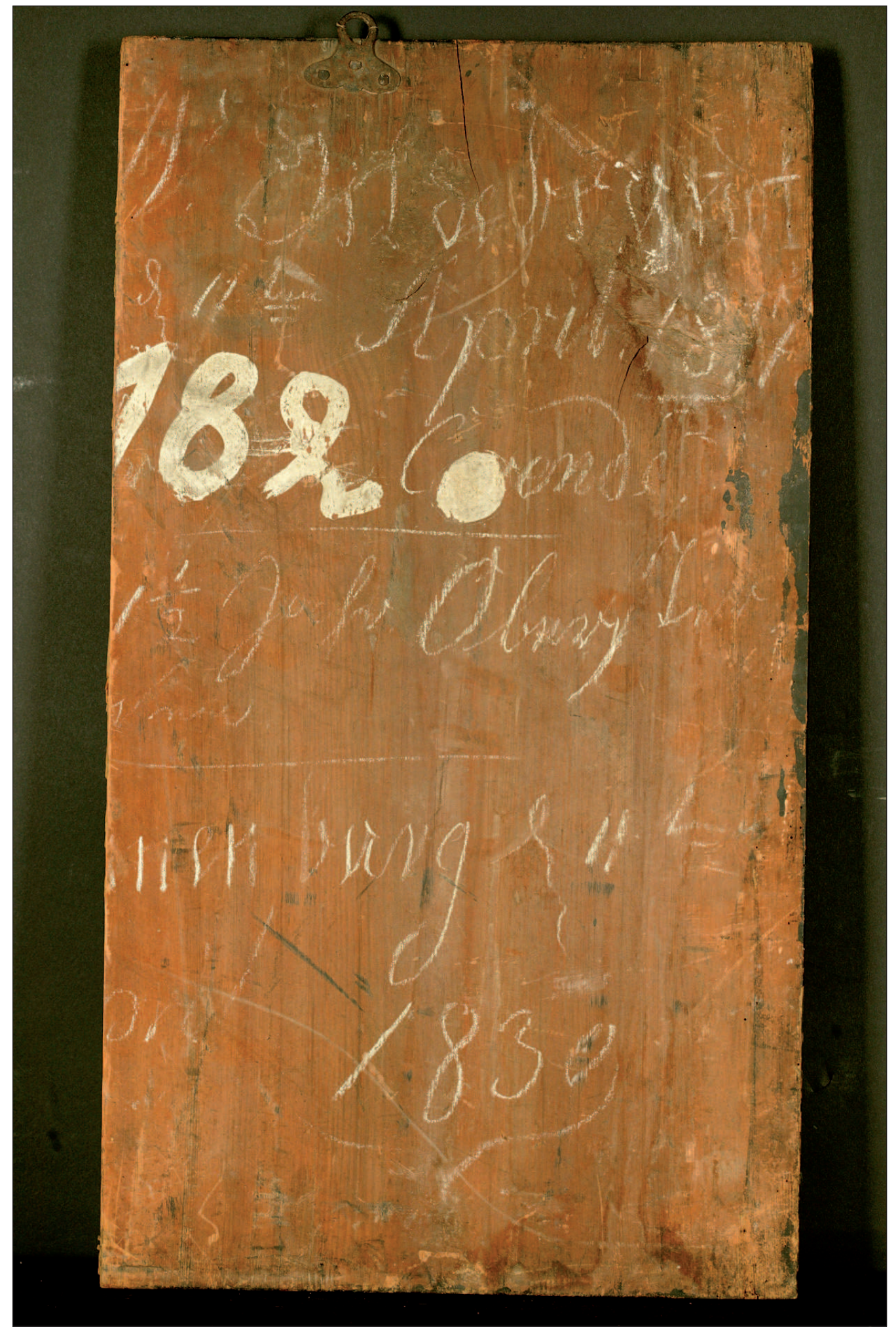

Il. 17. Odwrocie tablicy z herbem Wilhelma Christiana Gottloba von Pöllnitz przed konserwacją (fot. S. Smagłowski) 


\section{Summary}

\section{The mysterious history of the collection of heraldic shields of the Order of St. John in Słońsk and their conservation problems}

Representative heraldic shields executed on wooden boards, have been devoted the knights of the Order of St. John of the Bailiwick of Brandenburg. The capital of the bailiwick since the year 1426 was Słońsk, which neighbourhood since 1249 belonged to the margraviate.

The oldest among the shields date back to the $17^{\text {th }}$ and $18^{\text {th }}$ centuries, however the majority of them - and there was altogether ca. 1300 located in the castle and in the church - dates back to the mid- and late $19^{\text {th }}$ century, the period of very vivid activity of Balley Sonnenburg. The set of shields has been complemented still in the first half of $20^{\text {th }}$ century, even up to 1942 . Heraldic shields, on average $70 \mathrm{~cm}$ high and $50 \mathrm{~cm}$ wide, has been made in oil technique on oak, fir or pine boards, sporadically on canvas. They were divided into two groups. Bigger ones, more splendid and placed higher on the walls, were commemorating the grand masters.

In 1945 the shields, together with Słońsk archives have been acquired by the Central Archives of Historical Records in Warsaw, located in Pałac pod Blacha and later transferred to the Royal Castle in Warsaw. Presently there are 123 shields preserved in Poland, stored in the Delegacy of the Regional Conservation Office in Gorzów Wielkopolski.

In November 2004 four of the described shields, mostly in a wrack condition have been handed over to the Department of Conservation of Paintings and Polychrome Sculpture NCU in order to perform conservation and restoration within the framework of didactic activities. The paper contains description of technique of the original and the analysis of technique of the making, further on the state of preservation is being characterised. The destruction, mostly of mechanical character, consisting on the loss of large fragments of shields, occurred most probably at the end of World War II. Earlier the shields do not undergo any conservation treatment. The course of present conservation and restoration works has been discussed in detail, concentrating on the necessity of executing 
reconstruction of missing parts of the supports and paint layers. Conservation and restoration treatment of two shields - one dedicated to August Heinrich Graff von Wartensleben, the other dedicated to Georg Albrecht von Brandenburg have already been completed and the artefacts have been returned to the owner. The works on two remaining shields - one with the crest of Friedrich Ludwig Wilhelm Philipp von Vincke and the other one with the crest of Wilhelm Christian Gottlob von Pöllnitz will soon be completed. 